\title{
XVII. Yüzyılda İstanbul Medreselerinde Okutulan Kitaplar (Tereke Kayıtları Üzerine Bir Değerlendirme)
}

\author{
Ekrem TAK* \\ Bilgin AYDIN**
}

\begin{abstract}
$\ddot{O} z$
Bu çalı̧̧mada XVII. yüzyıl İstanbul'unda medrese talebelerinin okuduğu kitaplar tereke kayıtları üzerinden incelenmeye çalışılmıştır. Bilindiği gibi Osmanlı medreselerinde okutulan kitaplarla ilgili kaynaklarda birbirinden farklı birçok kitap adları geçmekte ve teorik olarak bu kitapların medreselerde okutulduğu kabul edilmektedir. Ancak bu kitapların hepsi medreselerde okutuluyorsa acaba bu durum medrese öğrencilerinin kitap koleksiyonlarına yansımış mıdır? Bunu tespit edebilmek için şeriyye sicilleri ve tereke kayıtları incelenmiş̧ir. Bu çalışmada başta Kısmet-i Askeriye Mahkemesi olmak üzere İstanbul mahkemelerine ait siciller taranarak 1089-1110 (1678-1698) tarihleri arasinda tesbit edilen medrese talebelerine ait 14 tereke kaydı değerlendirilmiştir. Bu terekelerde mevcut kayıtlardan vefat eden medrese talebelerinin öğrenim gördüğü medreseyi, memleketlerini, mirasçılarını, servetlerini, öldüklerinde medresede mevcut kitaplarını ve bu kitapların fiyatlarını, mensubu oldukları askerî ve idarî sınıfları ve varsa ticarî münasebetlerini öğrenmek mümkündür. .
\end{abstract}

Anahtar Kelimeler: Medreseler, talebeler, eğitim, kitaplar.

\footnotetext{
* Dr. Öğretim üyesi, İstanbul Medeniyet Üniversitesi, Bilgi ve Belge yönetimi, İstanbul, Türkiye.

Elmek: ekremtak@yahoo.com.

https://orcid.org/0000-0003-1386-6519

** Prof. Dr. İstanbul Medeniyet Üniversitesi, Bilgi ve Belge yönetimi, İstanbul, Türkiye.

Elmek: bilginaydin34@gmail.com.

https://orcid.org/0000-0003-1380-9733
}

Received Date / Geliş Tarihi: 29.08.2018

Accepted Date / Kabul Tarihi: 28.10.2018 


\title{
Tthe Books Reading in İstanbul Madrasahs in the XVII Century
}

\begin{abstract}
This study aims to examine the textbooks which the students would read during the course of their education in the madrasas in İstanbul during the seventeenth century through the probate records (tereke). As it is known, miscellaneous books have been mentioned in the resources related to the textbooks which were read in the Ottoman Madrasas and they are all theoretically accepted to have been taught in the madrasas. However, if all of them were read in the madrasas, could it be reflected on the book collections of the students? In order to reveal this, the court registers and the probate records have been examined. After going through the registers of the Istanbul courts, especially the Kismet-i Askeriye Tribunal, the 14 probate records of the madrasa students dated to the years of 1089-1110 (1678-1698) have been determined and evaluated. These records allow us to learn the hometowns, heirs and fortunes of the students who passed away and the madrasas where they studied. It is also possible to learn the books which the students left in the madrasas when they died, the prices of the books, the military and administrative classes they belonged to and the commercial relations if any.
\end{abstract}

Keywords: Madrasahs, students, education, books. 


\section{Extended Summary}

This study aims to examine the textbooks which the students would read during the course of their education in the madrasas in İstanbul during the seventeenth century through the probate estate inventories (tereke). As it is known, miscellaneous books have been cited in the resources related to the textbooks which were read in the Ottoman Madrasas by researchers and they are all theoretically accepted to have been taught in the madrasas. However, if that so, could it be reflected on the book collections of the students? In order to reveal that, the court records and the probate estate inventories have been examined thoroughly.

For this article, the court records (sicils) of Istanbul, especially the Kismet-i Askeriye Tribunal, have been searched and the 14 probate estate inventories belonging to the madrasa students dating from 1089 to 1110 (16781698) have been determined and studied. The inventories used in the study are respectively dated to 1089 (1678), 1092 (1681) (2), 1093 (1682), 1096 (1685), 1097 (1686) (4), 1099 (1688), 1101 (1689), 1103 (1691). , 1109 (1697) and 1110 (1698). The existing records in these inventories provide valuable information about the deceased students indicating where the deceased was from and in which school he was trained. They also give details about legal heirs, honorific titles which signified the membership in the military, administrative or religious establisments and commercial relationships if he had any. Besides, they include the itemized lists and appraised values of all inherited properties and books of the deceased student at the time of death. Therefore, all data which are recorded in the inventories have been investigated.

In the first section of the article, we explore the educational system in the Ottoman schools in the seventeeth century focusing on the instruction, curricula and duration of the education. Using the probate estate inventories determined, we examine the data on honorific titles, marital status and legal heirs of the deceased student and where he came from. 
The second section of the article is related to medrasa books and our main objective is to determine the total monetary values of the books of the deceased students registered into the inventories. According to our findings, the probate estate inventory with the highest number of books is the inventory dating to 1101, which includes 67 books. The most valuable one is the inventory dating to 1110 , which includes 44 books appraised as 13338 akçe. After each of the inventories has been evaluated in detail, the date of the inventory, the name of the deceased student whom the inventory belonges to, where the deceased was from and where he died have been indicated in the study. Furthermore, the books which the deceased left and their appraised values, whether they were sold or delivered to their heirs have been reflected.

In the third section of the article, the books recorded in the probate estate inventories have been evaluated after their classification according to their subjects headings. Thus, we have determined that 27 jurisprudence (F1qh), 27 grammar, 12 literature, 6 inheritance law (Feraiz), 12 logic, 5 rhetorics, 4 tenets of faith (akaid) and 5 religious code (ilmi hal) books were recorded. Under each subject heading, the names and numbers of the books and the dates of inventories which they were recorded in have been demonstrated in the charts and based on these charts, they have been analyzed depending on their value and frequency of presentation in the inventories. The books are also ranged from the most to the least recorded book. Each book has been evaluated regarding in which inventories it was recorded and how much it was appraised.

At the end of the article, the images and transcriptions of 14 probate estate inventories are demonstrated in a chronological order. 


\section{Giriş: XVII. yüzyılda Osmanlı Medreselerinde Tedris Sistemi}

Osmanlı medrese eğitiminin muhtevası ve süresi, günümüz modern eğitim sisteminden farklı olarak kural ve nizamlarla belirlenmiş belli bir müfredata ve sene esasına dayanmadığı için bu konudaki bilgilerimiz bazı rivayet ve anlatılarla sınırlı kalmaktadır. ${ }^{1}$ Medrese eğitiminin esaslarını doğrudan müderrisler tayin eder ve müderris ihtisas yaptığı her hangi bir ilim dalında o ilim dalının meşhur bir eserini okutarak yeterli bulduğu talebesine icazet verirdi. Müderrisler kendi okutacakları dersler için muhtelif risaleler kaleme alır, bazı eserler için şerh ve hâşiyel er yazarlard1. ${ }^{2}$

XIV. yüzyıldan XIX. yüzyıla kadar Osmanlı Devleti'nin yegâne eğitim kurumu olan medreselerde talebelere hangi kitapların okutulduğunu gösteren kaynaklar yeterli olmadığından her yüzyıl için detaylı olarak tespit etmek mümkün olamamaktadır. ${ }^{3}$ Bu konuda bir sınırlama ve idari düzenleme mevcut olmad1ğ için okutulan dersler asırlara göre değişmiş ve müderrislerin yetkisi dâhilinde kalmıştır. Bu sebeple Osmanlı medreselerinde okutulan ders veya kitapların hangi tarihten itibaren bir tertib ve nizam içinde okutulmaya başlandığ 1 belli değildir.

\footnotetext{
1 Osmanlı medrese talebelerinin öğrenim süreleri hakkında kesin bilgiler elimizde mevcut değildir. Tahsil müddeti, hem icazet alınan eser veya derslerin sayısına göre değişim göstermekte hem de muhtelif asırlarda yapılan düzenlemeler bu süreyi uzatıp kısaltabilmekteydi. Osmanlı biyografi eserleri, ulemanın eğitimiyle ilgili ayrıntılara girmediği için eğitimin süresinin ne kadar olduğuna dair bir soruya tatminkâr bir cevap verecek kadar fazla örnek elimizde bulunmuyor. Yalnız Şakayık-1 Numaniye'nin yazarı bu konuda bir istisna teşkil etmektedir. 901/1495 yılında doğan İsameddin Ahmed Efendi, XVI. yüzyıl başlarında bir Osmanlı medrese talebesi olarak, kendi öğrenim sürecini otobiyografisinde nakletmiş ve bu konudaki yegâne bilginin günümüze ulaşmasını sağlamıştır. Onun öğrenim süresi 20 yılı aşmış ve ancak 1525 yılında 30 yaşında iken müderris olarak Dimetoka'da meslek hayatına başlamıştı. (Taşköprüzade, eş-Şakaiku'n-Numaniyye: Osmanlı Bilginleri, çev. Muharrem Tan, İz yayıncılık, İstanbul 2007, s. 377-380.)

İsameddin Ahmed Efendi`nin öğrenim süresiyle ilgili kaydını destekleyen bir bilgi de Hırzı 'l-Müluk'da bulunmaktadır. $\mathrm{Bu}$ esere göre de Osmanlı medrese eğitimi 25-30 yaşlarına kadar sürmektedir. Bu yaşa kadar medresede okuması gerekli kitapları okuyup icazet alan talebeler "25-30 yaşında mülazım olup ya medreseye veya kadılı̆ga talip olur." (Yaşar Yücel, Osmanlı Devlet Teşkilatına Dair Kaynaklar, Türk Tarih Kurumu, Ankara 1988, s. 195.) Bu rakamlardan hareketle, ortalama beş yaşında öğrenime başlayan bir talebenin 20-25 y1llık bir öğrenim gördüğünü söyleyebiliriz.

2 İsmail Hakkı Uzunçarșıll, Osmanlı Devletinin İlmiye Teşkilatı, Türk Tarih Kueumu (TTK), Ankara 1988, s. 75-77.

3 Bu konudaki bazı çalışmalar için bkz: Şükran Fazlığlu, „Osmanlı Medrese Müfredatına Dair Çalışmalar: Nereden Nereye?“, Türk Araştırmaları Literatürü Dergisi -Türk Eğitim Tarihi, c. VI, S. 12 (İstanbul 2008), s. 593-609, Cevat İzgi, Osmanlı Medreselerinde İlim, İstanbul 1997, I-II; İhsan Fazlığlu, “Osmanlı Düşünce Geleneğinde 'Siyasî Metin' Olarak Kelâm Kitapları", TALIDD, S. 2 (2003), s. 379-398; Şükran Fazlığlu, "Manzûme Fî Tertîb El-Kutub Fî El-Ulûm ve Osmanlı Medreselerindeki Ders Kitapları”, Değerler Eğitim Dergisi, c. I, S. 1 (Ocak 2003), s. 97-111; Şükran Fazlıoğlu, “Ta 'lîm ile İrşâd Arasında: Erzurumlu İbrahim Hakkının Medrese Ders Müfredatı”, Dîvân İlmî Araştırmalar, S. 18 (2005/1). Erken dönem Osmanlı medreselerinde okutulan temel kitaplar, XII-XIII. Yüzyıllarda ortaya çıkmış ve zaman içerisinde medresede ders kitabı olarak okutulabilecek bir formda üretilmiş eserler olmalıdır. Bu bakımdan İslam dünyasında medreselerin gelişmesine bağlı olarak üretilmiş ve basitten gelişmişe doğru düzenlenmiş yeni bir kitap sistemi ortaya çıkmıştır.
} 
Fatih döneminde böyle bir teşebbüsün mevcut olduğu ifade edilse de kaynaklar bunu ayrıntılı bir şekilde anlatmamaktadır. Konu hakkında yegâne bilgi veren kaynak Gelibolulu Mustafa Âlî’nin Künhü'l-ahbâr'ıdır. Âlî, metnine bugüne kadar rastlanamayan Fatih'in tedris kanunundan "Der-beyân-1 nehc-i ulemâ ve bünyan-1 tarîk-i ashâb-1 dirâset ü kazâ" başlığı altında bahseder. ${ }^{4}$ Buna göre bir medrese talebesi üç aşamalı bir öğrenim görmektedir. Öğreniminin ilk devresinde sarf ve nahiv derslerinin yanısıra me ânî, bedî, beyan, heyet ve hendese dersleri görür. Bu evreyi tamamlayan talebe danişmend olmaya hak kazanmıştır. Danişmend ünvanını alan talebe öğreniminin ikinci aşamasında 25 akçeli Hâş̧iye-i Tecrîd medreselerinden birinde ders almaya başlayarak bir yıl ders görür. Bu sürede kendisini ispat ederse sonra aşağıdan yukarıya Miftâh, Kırkl, Haric, Dahil ve Sahn medreselerinde öğrenimini tamamlar. Her medresede üçer ders alır. Bu dersler usul, füru, tefsîr, kelam, me‘anî ve diğer ilimlerden olabilir. Gelibolulu, tertib kanununun veya uygulamasının Yıldırım Bayezid Han'dan itibaren mevcut olduğunu ileri sürer. Onun naklettiği bilgilerden Sahn medreselerinde ders kitapları olarak fikıhtan el-Hidâye'nin, usûl-i fikıhtan Şerh-i Adud ve Telvîh'in, hadisten Buhârî̀nin, tefsîrden Zemahşerî’nin el-Keş̧̧âf' ının ve Kadı Beyzâvî’nin tefsîrinin okutulduğu anlaşılmaktadır. Sahn'da ayrıca müderrislerin kendi seçecekleri kitapların da kullanıldığı söylenebilir. Tetimme medreselerinde ise Şerh-i Şemsiye ve İsfahânî okunması öngörülmüştür. İsmail Hakkı Uzunçarşı11, Gelibolulu Mustafa Âlî'nin tarihinden özetleyerek Osmanlı medreselerinde okutulan dersleri 20-25 akçelik Hâşiye-i Tecrîd medreselerinden başlayarak ve ayrıca ilim dallarına göre sınıflandırarak sistematik bir şekilde listelemiştir. ${ }^{5}$

Osmanlı medreselerinde tedris sistemi, yüzyıllar boyunca değişmekle beraber XVII. yüzyıldan itibaren sistemin belirli bir şekil aldığı görülmektedir. Hırzü'l-Müluk adlı eser, tedris sistemini şu şekilde resmetmektedir:

"Her tab-1 nüktedana hafi ve nihan değildir ki tarîk-i ilme çalışup danişmend olmak maksud idinen kimesne bir mikdar zaman evkatın, nahv ü sarfa ve sayir muhtasarata sarf ve mantık ve kelam ve me'ânî okuyup ba'dehu danişmend oldukda İstanbul'da olan Hâşiye-i Tecrid medreselerinün her birinde üçer dörder ay yatup şuğl eyleyüp, her müderrisden beş altı ders okuyup bu uslub üzere hareket idüp

4 Künhü'l-Ahbar, Fatih Sultan Mehmed Devri 1451-1481, c. II, haz. Hüdai Şentürk, TTK, Ankara 2003, 69-72.

5 Uzunçarşıll, İlmiye Teşkilatı, s. 19 
dört beş yıla değin Semaniye medreselerine varup anda dahi bir yıl mikdarı durup andan padişah medreselerine varup ve bi'l-cümle nice efazıl hidmetine yetişüp her birinden nice istifade ve istifaza idüp her vechile meleke ve istidad geldükten sonra yirmibeş otuz yaşında mülazım olup ya medreseye veya kadılığa talib olur."

Esere göre danişmend olmak isteyen bir kimse öncelikle sarf, nahiv, muhtasarat, mantık kelam ve me‘ânî okumalıdır. Sonra Hâşiye-i Tecrid medreselerinin her birinde üçer dörder ay kalarak her müderristen beş altı ders okumal1dır. Hâşiye-i Tecrid medreselerindeki derslerini dört beş yılda tamamlayan bir danişmend, Semaniye Medresesi 'ne geçerek bir yıl da burada ders görmektedir. Semaniye'den sonraki son aşama ise Süleymaniye Medresesi'dir. Süleymaniye Medresesi'ndeki öğrenimini tamamlayan danişmend 25-30 yaşlarında mülazım olmaya hak kazanmakta ve müderris ya da kadılığa aday olmaktadır.

Hırzü'l-Müluk yazarı, medrese eğitiminin ana gayesinin talebeye öncelikle Arapça sarf ve nahvi öğretmek olduğunu vurgular. "Sarf ve nahv görmemiş ve muhtasarat okumamış" cahillerin rüşvet ve şefaatle danişmend ve sonra da kadı olduklarını ve "Müslümanların davaların yalan yanlış görüp hükm idüp nice mefsedet-i azîmeye sebep" olduklarını söyler:

"Mesela bir divarun temelinde zelel muhtemel ola üstüvâr olmak ihtimâli yokdur. İlm-i şerîfin dahi esası sarf ve nahvdir. Nahv ve sarfda ve sâyir fünûn-1 âliyede câhil olan ulûm-1 âliyede dahi râcil olmak muhakkakdır. Bu mukaddimeden maksûd oldur ki şimdiki halde ulema ahvâli dahi muhtel olup meselâ sarf ve nahv görmemiş ve muhtasarat okumamış bir câhil ya mal kuvvetiyle ve yahud bir tarikle üç dört yıla değin danişmend olup ba'de ya rüşvet ile ve yahud şefâ' atle bir kadılık alup çıkup gidüp, varup kadılığında Müslümanların da'vaların yalan yanlış görüp hükm idüp nice mefsedet-i azîmeye sebep olur. Danişmend ve mülâzım ahvâli böyle olıcak sayir ahvâlleri bundan dahi harâbdır. Geçenlerde, bir danişmend, ibtidâ-i hareketinden beş yıla değin semaniyeye varsun diyü emr-i şerif olmışken asla icrâsına mukayyed olmazlar."

XVII. yüzyılda medrese öğrenimi hakkında bilgiler veren nadir müelliflerimizden biri de Evliya Çelebi' dir. Seyahatnamedeki kayıtlara göre Evliya Çelebi, İstanbul'daki öğrenim hayatının ilk basamağına bir sıbyan mektebi olan Ağaoğ- 
lu Mektebi'nde başlamış daha sonra Fatih semtinin Karaman mahallesinde Sadi Çelebi Dârülkurrâsında 11 yıl öğrenim görmüş ve bu medresede İbn-i Kesir'in Kıraat-i Seb 'asını ve Şatibi adlı eserleri okumuştur. Dârülkurrâlar diğer medreselerden farklı bir eğitim sistemine sahip olduğu için Evliya Çelebi buralarda Şemseddin el-Cezerî ve Ebu Muhammed Şatibi'nin eserlerinin okutulduğunu belirtir. Dârülkurrâlarda temel amaç kıraat eğitimi yani Kurân-1 Kerîm'in muhtelif kıraat imamlarına göre okunuşunun öğretilmesiydi. 9 yaşında hafız olan Evliya Çelebi'nin kıraat ilimlerine yönelmesi ve sesinin güzelliği dolayısıyla bu tür bir eğitimi tercih etmesi gayet tabii bir durumdur. ${ }^{7}$

Evliya Çelebi bir müddet de Şeyhülislam Hamid Efendi Medresesi'nde Ahfeş Efendi'den öğrenim görmüştür. Bu medresede yedi sene süren tahsil hayatı boyunca İbnülhacib'in (ö.1249) Şafiye (sarf) ve Kâfiye (nahv) adlı eserleri ile Kâfiye'nin şerhi olan Molla Câmî'nin Fevâidü'z-Ziyaiye'sini, Ahfeş Efendi'den İzzî’yi okudu. Kâfiye ve kıraat derslerine Enderun'a alındıktan sonra da devam etmiştir.

Yukarıda verilen biyografik malumatta da görüldüğü üzere bir Osmanlı medrese talebesi muhtelif medreselerde, muhtelif müderrislerden, farklı dersler okuyarak yetişmektedir. Bu bakımdan her bir talebenin ayrı bir tedris hikâyesi bulunmaktadır. Yalnız medrese basamağının ilki olan gramer öğreniminde standart bir ders veya eser silsilesi izlendiği Hırzü’l-Müluk'ün kayıtlarından anlaşılmaktadır.

\section{Tereke Kayıtlarının Değerlendirilmesi}

$\mathrm{Bu}$ araştırmada medrese talebelerine ait 14 tereke kaydı değerlendirilmiştir. Bu terekeler 1089-1110 yılları arasına aittir. 14 talebenin memleketlerine göre dağılımlarına baktığımızda bunlardan beşinin Anadolu, ikisinin ise Rumeli kökenli olduğu anlaşılmaktadır. Memleketleri belirtilmeyen 7 talebenin İstanbullu olduğunu kabul edebiliriz. Çünkü bunların miraslarının İstanbul dışına gönderildiğine dair bir kayıt bulunmamaktadır.

Vefat eden 14 talebeden 10 tanesinin terekesi varislerine teslim edilirken,

7 Nurettin Gemici, “Evliya Çelebi’nin Arapça bilgisi ve Arapça kaynaklarla ilişkisi üzerine gözlemler” Evliya Çelebi Seyahatnamesinin Yazılı Kaynakları, Editör: Hakan Karateke - Hatice Aynur, TTK Yayınları, Ankara, 2012, s. 187-199; Helga Anetshofer, "Seyahatname'de Dilbilime Dair Kaynaklar", Evliya Çelebi Seyahatnamesinin Yazılı Kaynaklarl, Editör: Hakan Karateke - Hatice Aynur, TTK Yayınları, Ankara, 2012, s. 279-280. 
2 talebenin varisi olmadığı ya da varislerinin kimliği belli olmadığı için terekesi beytülmale nakledilmiştir. Geriye kalan 1 tereke sahibinin emvâli vasîsine teslim olunmuştur. Bir talebenin ise borcu tereke yekûnundan çok olduğu için malları borç karşılığg alacaklılarına dağıtılmıştır.

Vefat eden medrese talebelerinin hepsi için tereke kaydı tanzim edilmiyordu. Bunu günümüze intikal eden tereke kayıtlarının çok sınırlı sayıda olmasından da anlıyoruz. Günümüze ulaşmış talebe terekeleri incelendiğinde; bu kayıtların daha çok ölen telebenin varislerinin kimliğini tespit etmek ve terekede kayıtlı mal varlığını müteveffanın ailesine ulaştırmak için düzenlendiği anlaşılmaktadır. $\mathrm{Bu}$ türden tereke sahiplerinin tamamının İstanbul dışında olması da terekelerin tanzim gayesini ortaya koymaktadır. Mesela Sinan Paşa Medresesi’nde öğrenim gören ve çok sayıda kitaba sahip olan İbrahim Çelebi'nin sahip olduğu eşya ve kitaplarının fiyatı kaydedilmemiştir. Çünkü onun sahip olduğu kitap ve eşyalar satılmamış, ailesine ulaştırılmak üzere kayıt altına alınmıştır.

Elimizdeki en eski tarihli tereke kaydı olan 2 Cemaziyelâhir 1089 tarihli belge, düzenlenişi bakımından talebe terekeleri için tipik bir örnektir. Bu belge, Fatih Sultan Mehmed medreselerinde öğrenim görmekte iken vefat eden Malatyalı Hüseyin Çelebi'nin varislerini, mal varlığını ve bu malların kimler aracılığıyla aileye ulaştırılacağını tespit etmektedir. Belgeye göre Hüseyin' in mal varlığ annesinin yanısıra iki erkek ve iki kız kardeşine kalmıştır. Bunun için Hüseyin' in mal varlığını, vasi tayin edilen Kadı Himmet Efendi tespit ettirecek ve malların satış işlemini gerçekleştirdikten sonra elde edilen parayı müteveffânın ailesine gönderecektir.

Talebe terekelerinin tamamında, talebenin sahip olduğu mal varlığ listelenirken ilk olarak kitaplar kaydedilmiştir. Bu eğilim kitaba ve dinî olana saygının bir tezahürü olarak değerlendirilebilir. Bunu kitap listesinin en başında Kurân’1 Kerîm'in yer almasından da anlamak mümkündür. Talebe terekelerinde kitap yanında hemen hemen daima kalem, kağıt gibi yazı malzemelerine, farklı türlerden eşyalara da rastlanılmaktadır. 2 Cemaziyelâhir 1089 tarihinde vefat eden Hüseyin Çelebi'nin terekesinde bir En 'âm-l aşerîf' in yanısıra deste halinde kağıt, kağıt tahtası, pirinç ve ağaç divitler ile mürekkep hokkası bulunuyordu. Bu terekede ilginç bir şekilde kılıç, yay ve tirkeş gibi silahlar da kayıtlıdır. Osmanlı askerî sınıfının dışında silah taşımanın yasak olduğu bir dönemde bir medrese talebesinin 
silahlara sahip olması onun bu zümre ile bir bağlantısı olabileceğini düşündürnmektedir.

Terekelerde talebelerin statüsünü gösteren (mülazım, muid, danişmend gibi) fazla bir kayıt yoktur. Fatih medreselerinden Ayak medresesinde kalan Abdülganî Efendi bir istisna teşkil etmekte olup, onun medresede "mülâzemet tarîkiyle sâkin" olduğu bildirilmiştir. ${ }^{8}$ Demekki Abdülganî Efendi, kadı ve müderris olmak için sıra bekleyen birisidir.

Talebelerin ünvanlarına bakıldığında 14 tereke kaydında müteveffa talebelerin genellikle iki farklı ünvanla kaydedildiği görülmektedir. Bunlardan ikisinin ünvanı çelebi, on tanesinin efendidir. Geri kalan 2 tanesinin ismi ise ünvansız olarak kaydedilmişitir.

14 tereke kaydının medreselere göre dağılımı dikkate alındığında bunların İstanbul'un 6 ayrı medresesine ait olduğu anlaşılmaktadır. Bunlar arasında Fatih ve Süleymaniye medreselerinde tahsil gören talebe sayısı diğerlerine nazaran fazladır. $\mathrm{Bu}$ medreselerde üçer talebenin vefatı dolayısıyla terekeleri tutulmuştur. Diğer medreselere bakılacak olursa Rüstem Paşa Medresesi'nde 2, Sinanpaşa Medresesi'nde 1, Karaçelebizâde Mahmud Efendi Medresesi'nde 1 ve Vânî Efendi Darülhadisi'nde bir talebenin tahsil görürken vefat ettiği anlaşılmaktadır. Bir talebe de Edirne'de bir medresede misafir iken vefat etmiştir. Muhtemelen bu talebenin İstanbul'daki medreselerden birinde kaydı bulunmakta idi.

Tablo: I

\begin{tabular}{|l|l|c|c|c|}
\hline \multicolumn{1}{|c|}{ Talebenin Adı } & \multicolumn{1}{|c|}{ Medresesi } & $\begin{array}{c}\text { Tereke } \\
\text { Tarihi }\end{array}$ & $\begin{array}{c}\text { Kitap } \\
\text { Adedi }\end{array}$ & $\begin{array}{c}\text { Kitapların } \\
\text { toplam } \\
\text { değeri } \\
\text { (Akçe) }\end{array}$ \\
\hline $\begin{array}{l}\text { Hüseyin Çelebi ibni eş-Şeyh } \\
\text { Ahmed }\end{array}$ & Fatih & 1089 & 1 & - \\
\hline Mustafa Efendi bin Şaban & Rüstem Paşa & 1092 & - & 8085 \\
\hline Hüseyin Efendi bin Osman & Süleymaniye Tıp & 1092 & 56 & 2031 \\
\hline Abdülganî Efendi ibni Ömer & Fatih & 1093 & - & 1180 \\
\hline İbrahim Çelebi ibni İbrahim & Sinan Paşa & 1096 & 29 & - \\
\hline
\end{tabular}

8 İstanbul Ş.S. (TSMA), 243, vr.7 


\begin{tabular}{|c|c|c|c|c|}
\hline $\begin{array}{l}\text { Fazlullah Efendi b. İbrahim b. } \\
\text { Abdüssamed }\end{array}$ & Fatih & 1097 & 10 & 1299 \\
\hline Hasan efendi bin Mustafa & Rüstem Paşa & 1097 & 28 & 6717 \\
\hline Tatar Ali Hoca & Edirne'de (boş) & 1097 & 12 & 766 \\
\hline $\begin{array}{l}\text { es-Seyyid Kasım Efendi bin } \\
\text { İsmail bin Kasım }\end{array}$ & Süleymâniye & 1097 & 23 & 1120 \\
\hline $\begin{array}{l}\text { Mehmed bin Ahmed Efendi bin } \\
\text { Mehmed }\end{array}$ & $\begin{array}{l}\text { Karaçelebizâde } \\
\text { Mahmud Efendi }\end{array}$ & 1099 & 16 & 1155 \\
\hline $\begin{array}{l}\text { Abdulkerim Efendi bin Ahmed } \\
\text { Efendi }\end{array}$ & Fatih & 1101 & 67 & 6129 \\
\hline $\begin{array}{l}\text { Mehmed Efendi b. Ömer b. } \\
\text { Mehmed }\end{array}$ & Süleymaniye & 1103 & - & 4865 \\
\hline İbrahim Efendi bin Himmet & $\begin{array}{l}\text { Edirne'de Üçşerefe- } \\
\text { li +Süleymaniye }\end{array}$ & 1109 & - & 4346 \\
\hline $\begin{array}{l}\text { Abdüsselâm bin Ahmed bin } \\
\text { Abdullah }\end{array}$ & $\begin{array}{l}\text { Vânî Efendi Dârü'l- } \\
\text { hadîsi }\end{array}$ & 1110 & 44 & 13388 \\
\hline
\end{tabular}

Medrese talebelerinin terekelerinden aile durumları hakkında bilgi edinmek de mümkün olmaktadır. Bu durumda 14 müteveffa talebenin üçünün miraslarının eşlerine ve çocuklarına kalmasından dolayı evli oldukları anlaşılmaktadır. 7 talebenin ise miraslarının kardeş, anne-baba ya da yakın akrabalara kalmasından dolayı bekâr olduklarına hükmedilebilir. 2 talebenin ise varisleri belli olmadığından mirasları beytülmale kalmıştır. 1 talebenin de borcu tereke tutarından çok olduğu için emvâli mirasçılara kalmayıp borçları için kullanılmıştır. 1 talebenin ise muhtemelen küçük yaşta kimsesiz kalmış olmasından dolayı mirası vasisine naklolunmuştur.

\section{Terekelerdeki Kitapların Toplam Değeri}

Terekelerde kitapların akçe üzerinden toplam değerlerine bakıldığı zaman 13388 akçe ile Vânî Efendi Darülhadisi'nde vefat eden Abdüsselâm bin Ahmed'in terekesindeki bıraktığı 44 kitabın ilk sırada yer aldığg görülmektedir. İkinci sırada Rüstem Paşa Medresesi'nde vefat eden Mustafa Efendi b. Şaban'ın 8085 akçelik terekesi vardır. Ancak Mustafa b. Şaban'ın kaç kitap bıraktığı terekede kaydedilmemiştir. Rüstem Paşa Medresesi'nde vefat eden diğer bir talebenin ise geride 6717 akçe tutarında 28 kitap bıraktığı görülmektedir. İncelenen terekelerde en düşük meblağ ise 766 akçe olup bu tereke geride 12 kitap bırakan Tatar Ali Hoca’ya aittir. 
Vefat eden talebelerin geride biraktıkları kitap sayılarına bakılacak olursa Fatih Medresesi'nden Abdülkerim Efendi 67 kitap ile en çok kitap sahibi talebe olarak ilk sırada yer almaktadır. Daha sonra Süleymaniye Tıp medresesinden Hüseyin Efendi b. Osman 56 kitapla ikinci, Vânî Efendi Daülhadisi'nden Abdüsselâm bin Ahmed ise 44 kitap ile üçüncü sirada gelmektedir. Sinan Paşa Medresesi'nden İbrahim Çelebi'nin 29, Rüstem Paşa Medresesi'nden Hasan Efendi'nin 28, esSeyyid Kasım Efendi'nin 21 kitabı bulunmaktadır.

\section{Medrese Talebelerine Ait XVII. Yüzyıl Tereke Kayıtları}

Talebe terekeleri arasında kitap kaydı bulunan en eski tarihli belge, Cemaziyelâhir 1089 tarihli olup Hüseyin Çelebi b. eş-Şeyh Ahmed'e aittir. ${ }^{9}$ Hüseyin Çelebi'nin terekesinde sadece bir En'âm-l şerîf kayıtlıdır. Herhalde Hüseyin Çelebi'nin kitapları bundan ibaret olmamalıdır. Çünkü terekesinde deste halinde kağıt, kağıt tahtası, pirinç ve ağaç divitler ile mürekkep hokkası bulunmaktadır. Kitap istinsahıyla uğraştığına göre onun başka kitapları da olmalıdır. H ü s e y i n Çelebi'nin1089 tarihli terekesinden sonra Rüstem Paşa Medresesi'nde sakin iken vefat eden Mustafa Efendi b. Şaban'ın 15 Rebiulahir 1092 tarihli terekesi ${ }^{10}$, kitaplarının zenginliğiyle dikkati çekmektedir. Kitaplarının toplam değeri 8085 akçeyi bulmaktadır. Mustafa Efendi b. Şaban'a ait kitapların başında diğer pek çok terekede olduğu gibi Kelâmullah şeklinde kaydedilen Kurân-ı Kerîm bulunmaktadır. 3000 akçe değerindeki bu Kurân-ı Kerîm terekedeki kitaplar içerisinde en pahalı eserdir. Muhtemelen yazı ve cildi bakımından değerli bir nüshadır. Bundan sonraki kitap Eşbâh ve Nezâir' dir. Fakat bu eserin müellifi belirtilmediği için bu alanda aynı adla kaleme alınan birçok eserden hangisi olduğunu tahmin etmek mümkün değildir. Eşbâh ve Nezâir, İslâm hukukundaki küllî kaideleri, benzer meselelerin tâbi olduğu ortak veya farklı hükümleri açıklamayı konu alan bir ilim dalının da adıdır. Bu dalda yazılan eserler de ortak bir adlandırmaya sahiptir. Dolayısıyla terekedeki kitap, bu türde eser vermiş müelliflerden herhangi birine ait olabilir. ${ }^{11}$

9 Mülga Beledi Kassamlığı, No.12, vr.93a.

10 İstanbul ŞS (TSMA), No.242, vr.18.

11 Süyûtî, Eşbâh ve Nezâir'i "fikhın hakikatına, esasına, kaynaklarına ve esrarına muttali olmayı sağlayan önemli bir ilim" diye tanımlar. Fıkıh literatüründe İbnü'l-Vekîl'in (ö. 716/1317) el-Eşbâh ve'n-nezâir'i bu isim altında yazılan kitapların ilki sayılmış, daha sonra bu alanda kaleme alınan eserler için de bir ölçüde model teşkil ettiği kabul edilmiştir. Yine bu alanda yazılan eserler arasında Tâceddin es-Sübkî'nin el-Eşbâh ve'n-nezâir' 'i, İbnü'l-Mülakkın'ın el-Eşbâh ve'n-nezâir' i, Süyûtî ve Zeynüddin İbn Nüceym'in aynı adla anılan eserleri zikredilebilir. (Mustafa Baktır, "Eșbah ve Nezair", Türkiye Diyanet Vakfi İslam Ansiklopedisi (DİA), c.XI (1995), s.457) 
Arapça gramer kitaplarının en meşhurlarından biri olan Çarperdi, listedeki üçüncü eserdir. Fakat Çarperdi'nin yanında listelenen üç eser daha bulunmaktadır. Bunlar eser veya yazar adı belirtilmeyen ve sadece Fârisî Lügat şeklinde kaydedilen bir eser ile Mutavassit ve Ferâiz-i Seydî adlı eserlerdir. Bu dört eser tek bir başlık altında kaydedilmiş olup bunların sonunda "alayı" kaydıyla dördünün toplam fiyatı yazılmıştır. Kavâ id-i Irâb ve Hâşiye-i Hayâli ve Şerh-i Akâid ve Dav ve Avâmil-i $M u$ 'ribî bir arada kaydedilmiştir. Terekedeki diğer kitaplar şunlardır: Muhtasarât-l Nevâzil, Kavâ'id-i Irâb-ı Zencâni, Hadis-i Erba‘în, Şerh-i Sekkâki, Muhtasar Ferâiz, Mültekâ, Kavâ'id-i Irâb Şerhi, Sadrü’ş-Şeri'a, Pendnâme, Şerh-i Akâid, Ebulleys, Mukaddime, Şerh-i Menâr.

Hüseyin Efendi bin Osman'a ait 1 Cemaziyelâhir 1092 tarihli tereke ${ }^{12}$, talebe terekeleri arasında en dikkat çekici olanıdır. Süleymaniye medreselerinden Tıp Medresesinde sâkin iken vefât eden Hüseyin Efendi bin Osman, geride 56 kitaplık bir koleksiyon bırakmıştır. Fakat maalesef bu terekedeki kitapların adları kaydedilmemiş ve eserler kayda geçirilirken sadece "kitab", "def"a kitab" ibarelerine yer verilmiştir. Muhtemelen mesleki tıp kitaplarından oluşan bu kolleksiyondaki kitap adları tespit edilemediği için veya buna lüzum görülmediğinden böyle bir usul tercih edilmiştir. Kitaplarının toplam değeri 1930 akçedir. Hüseyin Efendi'nin malları hayattaki tek varisi olan annesi Havva’ya ulaştırılmak üzere kayıt altına alınmıştı.

10 Şevval 1093 tarihli Abdülganî b. Ömer'e ait olan tereke ${ }^{13}$, medrese öğrenimini tamamlamış birisine ait olması dolayısıyla diğerlerinden farklıdır. $\mathrm{Bu}$ duruma, tereke kaydında "mülâzemet tarîkiyle sâkin" denilerek işaret edilmiştir. Konyalı Abdülganî, kadı veya müderris olmak için mülâzemetini tamamlamak üzere İstanbul'a gelmişti. Sahip olduğu kitaplar, bütün ilmiye mensuplarının terekelerinde görebileceğimiz üç kitaptan ibaretti. İbrahim Halebî, Mültekâ ve bir Fetva Mecmuası. Bir de not almak veya eser istinsah etmek için yanında bulundurduğu bir "Beyaz mecmu'a". Eser veya yazar adı belirtilmeyen Fetva mecmu'ası muhtemelen derleme bir çalışmaydı. Yazarı bilinen fetva mecmualarında yazar adı genellikle belirtilmiştir. Halebî veya Mültekâ bütün kadıların başlıca müracaat kitabıydı. Abdülganî b. Ömer'in terekesi, mülazımların yaşadıkları zor hayat şart- 
larının bir şahidi olup onun, Fatih medreselerinden birine sığınmış iken burada hastalanarak öldüğünü haber vermektedir. Borçları, geride bıraktığı mallarından fazla olduğu için 1180 akçe değerindeki dört kitabı ve ve eşyaları satılarak borçları ödenecekti. Abdülganî Efendi Konyalıydı ve Konya' da Fatma adında bir kızı ve Abdurrahman adında bir erkek kardeşi bulunuyordu. Ölmeden önce terekesinin satılmasını ve borçlarının ödenmesini vasiyet etmişti. Kalan paranın ise kızı ile kardeşine verilmesini vasiyet etmişti. Fakat terekesi, borçlarını karşılamadığı için geride onlara verilecek para da kalmamıştı.

Sinan Paşa Medresesi'nde öğrenim gören İbrahim, aslen Rumeli'nin Tırhala kazasından olup 1096 tarihli terekesinde 29 adet kitap kayıtlı bulunmaktadır. ${ }^{14}$ Bu kitaplar arasında Mantık, Kelam, Akâid ve Fıkıh ilmine ait kitaplar dikkat çekmektedir. Diğer terekelerle mukayese edildiğinde çok sayıda kitaba sahip olduğu söylenebilecek olan İbrahim Çelebi'nin kitaplarının fiyatları kaydedilmemiştir. Çünkü onun sahip olduğu kitap ve eşyalar satılmamış ailesine ulaştırılmak üzere kayıt altına alınarak bir sandık içerisinde vasisi Seyyid Ahmed Çelebi’ye teslim edilmiştir.

Fatih medreselerinden Başmedrese'de kalan Şamlı Fazlullah Efendi bu medresede misafir olarak ikamet etmekte iken vefat etmiştir. ${ }^{15}$ Fazlullah Efendi'nin 1097 tarihli terekesinde 10 adet kitap kaydedildiği görülmektedir. Terekede kayıtlı bu kitaplar arasında en kıymetli olanı 300 akçe ile kısaca Dürer olarak kaydedilmiş olan Dürerü'l-Hükkâm fì Şerhi Gureri'l-Ahkâm isimli fikıh kitabıdır. Bunu takiben terekenin ikinci kıymetli eseri ise 120 akçe ile kaydedilmiş En 'âm-l Şerîf'tir. Fazlullah'ın kitaplarının yekûnu 1359 akçe olarak kaydedilmiştir. Tereke kayıtlarına göre evli olduğu anlaşılan Fazlullah'ın mal varlığı kızlarına ve amcaoğluna intikal etmiştir. Fazlullah'ın eşinin isminin varisler arasında geçmemesi eşinin vefat ettiğini düşündürmektedir.

Rüstem Paşa Medresesi'nde öğrenim gördüğü sırada vefat eden Kütahya' 1 Hasan Efendi'nin 1097 tarihli terekesinde 28 adet kitap kayıtlı bulunmaktadır. ${ }^{16}$ Hasan Efendi'nin toplam 6717 akçelik metrukatı arasında en kıymetli eser 1500 akçe ile kaydedilmiş olan Kurân-ı Kerîm'dir. Bu döneme ait talebe terekelerinde bulunan diğer Kurân-ı Kerîm'ler ile mukayese edildiğinde vasat bir yazma olduğu

14 Mülga Beledî Kassamlığı, No.18, vr.93b.

15 Kismet-i Askeriye, No.12, vr.57a.

16 K1smet-i Askeriye, No.12, vr.110b-11a. 
anlaşılmaktadır. Hasan Efendi’nin 1205 akçe değerindeki üç kitabı bir arada kaydedilmiş olup bunlar Hutût-ı Kadl, Kenz, Def'a Kadı adlı kitaplardır. Terekenin diğer bir kıymetli kitabı ise 750 akçelik Meşârık-ı İbn-i Melek'tir. Bu eser “İbn Melek" lakabıyla meşhur İzzeddin Abdüllatif er-Rûmî'nin Mebâriku'l-Ezhâr fî Şerhi Meşâriki'l-Envâr ${ }^{17}$ adlı eseridir. Terekede kayıtlı bulunan en düşük fiyatlı kitap ise 5 akçelik Kavâ 'id-i Kurân'dır. Hasan Efendi'nin muhtemelen ailesinden hiç kimse hayatta olmadığı için mal varlığı Kütahya’nın Şeyhli kazasında bulunan amcaoğullarına kalmıştır.

Edirne'de ismi belirtilmeyen bir medresede vefat eden Tatar Ali Hoca'nın ise terekesinde 12 adet kitap vardır. ${ }^{18}$ Ali Hoca'nın kitaplarının yekûnu 745 akçe olarak hesaplanmıştır. Bu kitaplar arasında en kıymetli olan Tecvîd-i Kurân ma 'a Musavverât'ın fiyatı 180 akçedir. Terekede kayıtlı bulunan kitap arasında en düşük değere sahip olan eser ise Lugât-i Ferişte ma 'a En 'âm-ı Şerîf'tir. Bu iki esere 16 akçe fiyat takdir edildiği görülmektedir. 44 akçeye satılan Mecmu' $a-i$ Türk̂̂̀ den ise iki adet bulunmaktadır. Tatar Ali Hoca'nın tespit edilebilen bir varisi olmadığ 1 için mal varlığ 1 beytülmale verilmiştir.

İstanbul'da Süleymaniye medreselerinin birinde vefat eden ve aslen Ankaralı olan es-Seyyid Kasım Efendi bin İsmail'in 1097 tarihli terekesinde 23 kitap kaydedilmiştir. ${ }^{19}$ Terekede bu kitapların yekûnunun 1120 akçe olduğu belirtilmiştir. Kasım Efendi'nin sahip olduğu kitaplar arasında en kıymetlisi 500 akçelik Eşbâh Nezayir isimli kitaptır. Kasım Efendi'nin mirası ise boşandığı eşine ve babasına teslim edilmiştir.

Aslen Eskişehirli olan Mehmed bin Ahmed Efendi İstanbul'da Karaçelebizâde Mahmud Efendi Medresesi'nde vefat etmiştir. ${ }^{20}$ Mehmed vefat ettiğinde arkasında yekûnu 1155 akçe tutan 16 adet kitap bırakmıştır. 1099 tarihli terekede üçüne birden 315 akçe değer biçilmiş olan Mültekâ ve Lârî ve Füsul-i Hall-i Akd isimli kitaplar terekenin en değerli eserleri olarak kaydedilmiştir. Mehmed'in mirası Eskişehir'de yaşayan Abdullah Çelebi ve İbrahim Çelebi isminde iki kardeşine kalmıştı.

17 Mefail Hızlı, "Osmanlı Medreselerinde Okutulan Dersler ve Eserler”, Uludağ Üniversitesi Illahiyat Fakültesi Dergisi, XVII/1 (2008), s.36.

18 Kismet-i Askeriye, No.12, vr.188a.

19 Kismet-i Askeriye, No.12, vr.137b-138a.

20 Kismet-i Askeriye, No.13, vr.27b-28a. 
İstanbul'da Fatih Sahn-1 seman medreselerine bağlı Çifte Baş medresesinde vefat eden Abdulkerim Efendi bin Ahmed Efendi arkasında sayıca oldukça çok kitap bırakmıştır. Abdulkerim Efendi'nin 1101 tarihli terekesinde 67 kitabı bulunmaktadır. Toplamı 6129 akçe olan kitaplar satılarak bedeli kız kardeşi ve erkek kardeşi arasında taksim edilmiştir.

Aslen Rumeli’nin Filorina kazasından olan Mehmed Efendi b. Ömer b. Mehmed Süleymaniye Darülhadisi'nde öğrenim görürken vefat etmiştir. Mehmed Efendi'nin 1103 tarihli terekesinde 26 kitap vardır. Toplam yekûnu 4865 akçe tutan kitapların içinde en kıymetlisinin tereke tutarının neredeyse yarısına tekabül eden 2151 akçelik kıymetli bir Kuran-1 Kerim'in olduğu görülmektedir. Geriye kalan yekûnun içerisinde ise Mültekâ adlı fikıh kitabı 400 akçeye ve bir Farsça lügat 250 akçeye satılmıştır. Tereke kaydından anlaşıldığına göre ailesinden hiç kimsesi hayatta olmayan Mehmed Efendi'nin mirasının erkek kardeşinden olan iki kız yeğenine teslim edildiği belirtilmiştir.

Edirne'de Üçşerefeli Medrese'de eğitim görmekte iken vefat eden İbrahim Efendi b. Himmet, İstanbul'da Süleymaniye Medresesi'nde bir odada misafir olarak kalmaktaydı. İbrahim Efendi'nin 1109 tarihli terekesinin İstanbul şeriyye sicillerine kaydedilmiş olması onun ya eğitim ya da mülazamet için İstanbul'da bulunduğunu düşündürmektedir. Terekesinde 39 kitap kaydedilen İbrahim Efendi'nin kitaplarının değeri belirtilmemiştir. İçinde Evrak ve yazı takımı ( $k u$ bur devat) da kayıtlı bulunan terekenin toplam yekûnu 4346 akçedir. Kitaplara ait toplam değer ise evrak ve kubur devat düşüldükten sonra 4310 akçedir. Terekenin sonunda İbrahim Efendi'nin mirasının ne yapıldığına ve ailesinden herhangi bir varisinin olup olmadığına dair bir bilgi kaydedilmemiştir.

XVII. yüzylla ait tespit edilebilen son talebe terekesi 1110 tarihli olup aslen Rumelili olan Abdüsselâm bin Ahmed bin Abdullah'a aittir. İstanbul'da Bahçekapısı yakınlarında Vânî Efendi Dârü'l-hadîsi'nde eğitim görürken vefat eden Abdüsselâm sayıca kitabı fazla olan nadir talebelerdendir. Geride 44 kitap bırakan Abdüsselâm'ın bıraktığı bu kitapların yekûnu 7068 akçedir. Bunlardan satılanların değerinin 6320 akçe olduğunu terekedeki "Yekûn-1 kütüb-i mebî‘a 6320" kaydından anlıyoruz. Bu kitaplardan en kıymetli olanlarından biri 1200 akçeye satılan Dürer Gurer kitabıdır. Ayrıca 2 adet Fenarî de 920 akçeye satılmıştır. Terekede kayıtlı kitaplar arasında kıymetli sayılabilecek bir kitap da 600 akçeye 
satılan Bostan ma 'a Şem ' $’$ ' dir. Ancak hatırı sayılır sayıda ve kıymette kitabı bulunan Abdüsselâm'ın bir varisi ya da akrabasının varlığı bilinmediği için terekesi beytülmale kalmıştır.

\section{Kitapların Konularına Göre Değerlendirilmesi:}

Osmanlı medreselerinde okutulan kitaplar, medrese talebelerini gelecekte icra edecekleri mesleklere hazırladığı için başta fikıh olmak üzere çok farklı alanlara ait olabilmektedir. Bu bölümde medreselerde okutulan kitaplar konularına göre sınıflandırılmış ve terekelerde en çok rastlanan eserler değerlendirilmiştir.

\section{Fıkıh kitapları}

Osmanlı medreselerinde ders kitabı olarak okutulan Hanefî fıkıh kitapları aynı zamanda, kadıların şerî meselelerde verdikleri hükümlerin başlıca kaynağı idiler. 1089-1110 tarihleri arasında 14 tereke kaydında 50 fikıh kitabı kayıtlıdır. Tereke kayıtlarına baktığımız zaman en sık rastlanılan kitapların başında Halebî

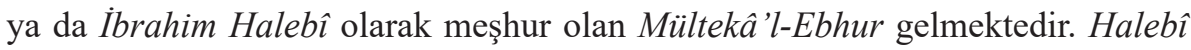
Osmanlı medreselerinde fıkıh eğitiminin başlıca eseridir. Bu esere 1089-1110 tarihleri arasında 14 tereke kaydının onikisinde rastlanmaktadır. Bunlardan 5'i Mültekâ, 3'i Mültekâ'l-Ebhur, 4'ü ise İbrahim Halebî şeklinde kayıtlıdır.

F1kıh kitaplarında ikinci sırada 3 terekede geçen Muhtasar gelmektedir. Muhtasar birbirinden farklı eserlere yapılmış şerhlere verilen ortak bir isimdir. F1kıh kitapları arasında adı sık geçen diğer bir kitap da, 3 terekede geçen Dürer'dir. Bu eser, tereke kayıtlarının birinde Dürer, ikisinde ise Dürer ve Gürer şeklinde birlikte kaydedilmiştir. 14 terekenin üçünde adı geçen kitaplardan diğerleri ise Eşbâh Nezâyir ve Sadru'ş-şeri 'a'dır. Her iki eser de üç terekede aynı isimle kaydedilmiştir.

F1kıh eğitiminin önemli bir eseri olan Kudûrî de 3 talebenin terekesinde yer almaktadır. İmam Ebu'l-Hüseyn Ahmed b. Muhammed el-Kudûrî el-Bağdadî’nin (ö.1036) Hanefî fikhına dair yazdığg Muhtasaru'l-Kudûrî adıyla tanınan kitabının çok sayıda şerhi yapılmış ve eser Osmanlı medreselerinde "Kud̂urî" adıyla okutulmuştur. Bu eser 3 terekenin ikisinde Kudûrî olarak kaydedilirken birinde Şerh $-i$ Kudûrî şeklinde kaydedilmiştir. 
Dönemin fikıh kitaplarından olan Şerh-i Menâr da 2 terekede geçmektedir. Bu eser Ebu'l-Berekât Hafizüddin en-Nesefî’nin (ö.1310) Hanefî fikıh usulü üzerine yazdığı Menârü'l-Envâr adlı eserin şerhidir. Metn-i Menâr olarak kaydedilen eser ise Menârü'l-Envâr olmalıdır.

14 terekenin ikisinde geçen bir diğer fikıh kitabı da Muhtar'dır. Alâüddîn Muhammed b. Alî b. Muhammed el-Haskefî ed-Dımaşkî'ye ait olan bu eserin tam adı ed-Dürrü 'l-muhtâr' dır. Eserde hanefî mezhebindeki sahih görüşlere ve birçok fikhî meseleye muhtasar şekilde yer verilmektedir. Bu sebeple çok rağbet görmüş ve medreselerde okutulmuş bir kitaptır.

1089-1110 tarihleri arasında tespit edilen 14 terekede bunlardan başka tespit edilmiş 20 fıkıh kitabı daha bulunmaktadır. Terekelerde adları geçen fikıh kitapları şunlardır:

Tablo I

Tereke Kayıtlarında Geçen Fıkıh Eserleri

\begin{tabular}{|l|c|c|}
\hline Eserin Adı & $\begin{array}{c}\text { Terekelerdeki } \\
\text { Sayısı }\end{array}$ & Geçtiği Tarih \\
\hline İbrahim Halebî (Mültekâ) & 12 & $1092-1110$ \\
\hline Muhtasar & 3 & $1101-1110$ \\
\hline Dürer & 3 & $1097-1110$ \\
\hline Eşbâh Nezâyir & 3 & $1092-1097$ \\
\hline Sadru'ş-şeri‘a & 3 & $1092-1097$ \\
\hline Kudûrî & 3 & $1097-1109$ \\
\hline Şerh-i Menâr & 2 & 1092 \\
\hline Muhtâr & 2 & $1097-1109$ \\
\hline Berdaî & 1 & 1097 \\
\hline Câmi'u'l-Fetâvâ & 1 & 1097 \\
\hline Eczâ-i Hidâye & 1 & 1097 \\
\hline Hâşiye-i Muhtasar & 1 & 1096 \\
\hline Kenz & 1 & 1097 \\
\hline Kitâbu Müştemilüıl-Ahkam fi'l-Fıkhi’ş-Şerif & 1 & 1096 \\
\hline Kitâbü>t-Telvih & 1 & 1096 \\
\hline Lisânü’l-Hükkâm & 1 & 1099 \\
\hline Mecma'u'l-Bahreyn alay1 & 1 & 1097 \\
\hline Meşârık-1 İbn-i Melek & 1 & \\
\hline
\end{tabular}




\begin{tabular}{|l|l|l|}
\hline Muhtarat-1 Nevâzil & 1 & 1092 \\
\hline Münye & 1 & 1103 \\
\hline Sükûk-1 Hâcibzâde & 1 & 1101 \\
\hline Şerh-i Lübâb & 1 & 1101 \\
\hline Tavzîh & 1 & 1109 \\
\hline Tercih-i Beyyinân & 1 & 1109 \\
\hline Vikâye & 1 & 1097 \\
\hline Zübdetü'l-Fetâvâ nâk1s âhir & 1 & 1101 \\
\hline Kitab-1 Tavzih & 1 & 1096 \\
\hline
\end{tabular}

\section{Gramer kitapları}

Osmanlı medreselerinde gramer alanında okutulan birçok eser vardır ve bunlar uzun yillar medreselerde okutulmuştur.

1089-1110 tarihleri arasında 27 farklı gramer kitabı 71 defa geçmektedir. Bu dönemde en çok rastlanan gramer kitabı kısaca Dav olarak kaydedilen ed-Dav “ ale'l-Misbâh'tır. 14 terekenin yedisinde geçen bu eser, 5 terekede Dav şeklinde, birinde Hayâlı̂ Dav, birinde de Nahve müte 'allik Dav olarak kaydedilmiştir.

Osmanlı medreselerinde çokça okutulan İbni Hişam'a ait Kavâ 'id-i I'râb adlı eser 14 terekenin beşinde geçmektedir. 5 terekenin üçünde bu şekilde yazılan eser, birinde Kavâ 'id-i I'râb Şerhi, diğerinde ise Kavâ'id-i I'râb-ı Zencânî şeklinde kaydedilmiştir.

Gramer alanında en sık rastlanan kitaplardan biri de Molla Câmî̀ dir. Aslında Kâfiye'nin şerhi olan ve asıl adı el-Fevâidü'z-Ziyâiyye fî Şerhi'l-Kâfiye olduğu halde Molla Câmî (1414-1492) tarafından yazıldı̆̆ı için Molla Câmî adıyla bilinen nahiv kitabı en yaygın gramer kitabı olarak dikkati çekmektedir. İncelediğimiz 14 terekenin beşinde adı geçmektedir. Ancak bir kayıtta metin eksik olduğundan Molla Câmî (Nâkıs) olarak belirtilmiştir.

Gramer alanında sık rastlanan kitaplardan biri de İbni Hâcib unvanıyla bilinen Osman b. Ömer tarafindan yazılmış olan Kâfiye isimli eser olup 5 farklı terekede yer almaktadır. 5 terekenin ikisinde Kâfiye olarak kaydedilen eser, birinde Kâfiye mecmu 'ası, birinde Kâfiye Mu'ribî, diğerinde ise Şerh-i kâfiye olarak kaydedilmiştir.

5 terekede kayıtlı bulunan diğer bir gramer kitabı da Avâmil'dir. 2 tereke kaydında Avâmil olarak geçen kitabın ismi diğer terekelerde, Avâmil Mu 'ribî, Mu 'rib-i Avâmil ve $M u$ 'rib olarak farklı şekillerde yazılııştır. 
Osmanlı medreselerinde okutulan diğer gramer kitaplarından Sarf, Iftitâh, Mutavassıt, Şafiye gibi kitaplar 14 terekenin içinde dörder defa geçmektedir. Aynı şekilde Çarperdi, Şerh-i Dibâce, Dinkoz, Enmuzec de üçer defa geçmektedir. 14 terekenin ikisinde geçen kitaplar ise Şerh-i İzzî, Kavâ 'id-i Kurân, Nahiv'dir.

\section{Tablo II}

Tereke Kayıtlarında Geçen Gramer Kitapları

\begin{tabular}{|c|c|c|}
\hline Eserin Adı & $\begin{array}{l}\text { Terekelerdeki } \\
\text { Sayısı }\end{array}$ & Geçtiği Tarih \\
\hline Dav (Hayali Dav, Nahve müte'allik Dav) & 7 & $1092-1110$ \\
\hline $\begin{array}{l}\text { Kavâ'id-i i'râb (Kavâ'id-i İ'râb Şerhi, Kavâ'id-i İârâb-1 } \\
\text { Zencânî) }\end{array}$ & 5 & $1092-1101$ \\
\hline Molla Câmî & 5 & $1092-1110$ \\
\hline $\begin{array}{l}\text { Kâfiye (Kâfiye mecmu'as1, Kâfiye-i Mu'ribî, Şerh-i } \\
\text { Kâfiye) }\end{array}$ & 5 & $1092-1110$ \\
\hline Avâmil (Avâmil Mu'ribi, Mu'rib-i Avâmil, Mu'rib) & 5 & $1092-1110$ \\
\hline Sarf & 4 & 1097-1109 \\
\hline İftitâh & 4 & $1097-1110$ \\
\hline Mutavassit & 4 & $1092-1110$ \\
\hline Şâfiye & 4 & $1096-1110$ \\
\hline Çarperdi & 3 & $1092-1110$ \\
\hline Şerh-i Dibâce & 3 & $1096-1110$ \\
\hline Dinkoz & 3 & $1097-1110$ \\
\hline Enmuzec & 3 & $1103-1109$ \\
\hline Şerh-i İzzî & 2 & 1096-1110 \\
\hline Nahiv & 2 & $1109-1110$ \\
\hline Kavâ‘id-i Kurân & 2 & 1097-1101 \\
\hline Diba[ce] şerhi & 1 & 1103 \\
\hline Kavâ'id-i Sarf & 1 & 1103 \\
\hline Mecmu'a-i Sarf & 1 & 1110 \\
\hline Şerh-i Merâh & 1 & 1110 \\
\hline Tecvid-i Birgili & 1 & 1109 \\
\hline Câmî & 1 & 1103 \\
\hline Ecrumiyye & 1 & 1103 \\
\hline Elfiyye-i İbn-i Mâlik & 1 & 1096 \\
\hline Hacı Baba & 1 & 1109 \\
\hline Hasan Paşa & 1 & 1097 \\
\hline
\end{tabular}




\section{Edebiyat Kitapları}

14 terekede edebiyat ve aynı zamanda dil öğretimi ile alakalı kitapların sayıs 19 olup bunlar bu dönem talebelerinin edebî eğilimlerini ve genellikle Farsça öğrenimi esnasında kullandıkları kitapları göstermektedir. 19 edebiyat kitabından dördü Şirazî'nin meşhur Gülistan isimli kitabıdır. Edebiyat kitapları arasında ikinci sırada Arûz, Ta 'b̂̂rnâme ve Bostan kitapları gelmektedir. Her üç kitap da 14 terekenin ikisinde geçmektedir. Terekelerde adı geçen diğer edebî kitaplar ise şunlardır:

\section{Tablo III}

Tereke Kayıtlarında Geçen Edebiyat Eserleri

\begin{tabular}{|l|c|c|}
\hline \multicolumn{1}{|c|}{ Eserin Adı } & Terekelerdeki Sayısı & Geçtiği Tarih \\
\hline Ta‘birnâme & 2 & $1101-1110$ \\
\hline Arûz & 2 & $1099-1101$ \\
\hline Bostan & 2 & 1110 \\
\hline İzâh-1 Me‘ânî & 1 & 1101 \\
\hline Dîvân-1 Câmî & 1 & 1101 \\
\hline Dîvân-1 Merâkî & 1 & 1101 \\
\hline Gülistan Şem‘îsi? & 1 & 1097 \\
\hline Şerh-i ebyât & 1 & 1110 \\
\hline Şerh-i Kaside-i Bürde & 1 & 1099 \\
\hline Şem‘̂̀ & 1 & 1110 \\
\hline Hâfız & 1 & 1110 \\
\hline Şem‘i & 1 & 1110 \\
\hline
\end{tabular}

\section{Ferâiz Kitapları}

İslam miras hukukuna dair ferâiz kitapları da terekelerde sıkça geçen kitaplar arasındadır. 14 terekenin üçünde geçen bu kitapların 5 tanesi Ferâiz şeklinde, 3 tanesi Metn-i Ferâiz şeklinde, 2 tanesi bir nakıs kaydı ile Ferâiz-i Seydî şeklinde kaydedilmiştir. Birer defa kaydedilen diğer ferâiz kitaplarının ismi ise Kavâ'id-i Ferâiz, Mecmua ani'l-Ferâiz, Muhtasar Ferâiz şeklindedir. 
Tablo IV

Tereke Kayıtlarında Geçen Ferâiz Eserleri

\begin{tabular}{|l|c|c|}
\hline Eserin Adı & Terekelerdeki Sayısı & Geçtiği Tarih \\
\hline Ferâiz & 5 & $1096-1110$ \\
\hline Metn-i Ferâiz & 3 & $1101-1109$ \\
\hline Ferâiz-i Seydi & 2 & 1092,1101 \\
\hline Kavaid-i Ferâiz, & 1 & 1092 \\
\hline Muhtasar Ferâiz, & 1 & 1092 \\
\hline Mecmu'a ani'l-Ferâiz & 1 & 1096 \\
\hline
\end{tabular}

\section{Mantık Kitapları}

14 terekede mantığa dair sıkça karşılaşılan eserlerin başında Kutb, Kutbuddin, Kutbuddin Seyyid olarak üç farklı şekilde yazılan kitap gelmektedir. 14 terekede mantık ilmine dair birden fazla görülen kitaplardan biri de Muhyiddin olarak bilinen Hüsam-1 Kati'nin Hâşiyesidir. Bu eser de terekelerde 2 defa geçmektedir. Terekelerde adı geçen diğer mantık kitapları ise şunlardır:

Tablo V

Tereke Kayıtlarında Geçen Mantık Eserleri

\begin{tabular}{|l|c|c|}
\hline Eserin Adı & Terekelerdeki Sayısı & Geçtiği Tarih \\
\hline Kutb (Kutbuddin, Kutbuddin Seyyid) & 3 & $1096-1109$ \\
\hline Muhyiddin (Hüsam-1 Kati) & 2 & $1096-1110$ \\
\hline Fenarî & 1 & 1110 \\
\hline Hâşiye-i Küçük & 1 & 1097 \\
\hline Hüssam-1 Kati & 1 & 1096 \\
\hline İsagoci & 1 & 1101 \\
\hline Kazımir & 1 & 1099 \\
\hline Kul Ahmed ale'l-Fenari & 1 & 1096 \\
\hline Mantık & 1 & 1109 \\
\hline Metali & 1 & 1092 \\
\hline Mirzacan Kadızade & 1 & 1096 \\
\hline Sâdeddin & 1 & 1097 \\
\hline
\end{tabular}




\section{Belagat Kitapları}

Osmanlı medreselerinde sıkça okutulan Belagat ilmine ait eserlerden 14 terekede 5 kitabın ismi 12 defa geçmektedir. Bunlardan en çok adı geçen kitap tam adı Telhîsü'l-miftah olan ancak terekelerde Telhis, Metn-i Telhîs ya da Metn-i Miftah olarak kaydedilen kitaptır. Bu kitaba 14 terekenin dördünde rastlanmaktadır.

S1k geçen belagat kitaplarından bir diğeri de Ta 'lim̂̂'l-müte 'allim olarak kısaltılan ve tam adı Ta 'limü'l-müte 'allim tarîkü't-te 'allüm olan eserdir. 14 terekenin üçünde geçen bu kitabın biri Mukaddime-i Ta 'lîm-i Müte 'allim şeklinde kaydedilmiş olduğundan eserin sadece mukaddime kısmı olmalıdır. Diğer iki kitaptan biri ise Ta 'limû'l-Müte 'allim ma 'a şerh şeklinde şerhi ile birlikte kaydedilmiştir.

14 terekede adı geçen belagat kitaplarından Mutavvel de üç defa geçmektedir. Ancak bunlardan birisi eksik nüsha olduğu için Seyyid ale 'l-mutavvel nâkıs şeklinde kaydedilmiştir.

Terekelerde tespit edilen belagat kitaplarından Risâle-i Istiâre ve Risâle-i Vaziyye? ise birer defa geçmektedir.

Tablo VI

Tereke Kayıtlarında Geçen Belagat Eserleri

\begin{tabular}{|l|c|c|}
\hline Eserin Adı & Terekelerdeki Sayısı & Geçtiği Tarih \\
\hline Telhîs (Metn-i Telhîs, Metn-i Miftâh) & 4 & $1092-1110$ \\
\hline $\begin{array}{l}\text { Ta'lîm-i müte'allim (Mukaddime-i } \\
\text { Ta'lîm-i Müteallim) }\end{array}$ & 3 & $1097-1110$ \\
\hline Mutavvel (Seyyid ale'l-mutavvel nâkıs) & 3 & 1101 \\
\hline
\end{tabular}

\section{Lügat Kitapları}

Lügat kitapları medrese talebelerinin her dönemde sıkça kullandıkları kitaplardandır. Bu sebeple bu dönemde de 14 terekenin 9'unda lügat kitaplarının adı geçmektedir. Bu 10 lügatin dördü bir Farsça-Türkçe sözlük olan Şâhidî’ dir. Ahterî, Fârisî lügat, Lugât-i Ferişte, Lugât-i Türkî̀ma 'a Arabî, Lügât-ı Fârisî gibi lügatler de 14 terekede adı geçen diğer sözlüklerdir. 
Tablo VI

Tereke Kayıtlarında Geçen Lügat Eserleri

\begin{tabular}{|l|c|c|}
\hline Eserin Adı & Terekelerdeki Sayısı & Geçtiği Tarih \\
\hline Şâhidî & 4 & $1101-1109$ \\
\hline Ahterî & 1 & 1101 \\
\hline Farisî lügat & 1 & 1092 \\
\hline Lugât-1 Ferişte & 1 & 1097 \\
\hline Lugât-1 Türkî ma'a Arabî & 1 & 1110 \\
\hline Lügât-1 Fârisî & 1 & 1103 \\
\hline
\end{tabular}

\section{Akâid Kitapları}

Medrese talebeleri tarafindan okunan eserler arasında akaid ilmine ait eserler de bulunmaktadır. 14 terekede dört farklı eserin adı 9 defa geçmektedir. Bunlardan en sık kullanılanı ise Taftazani'nin Şerhu'l-Akâid adlı kitabıdır. Bu kitap terekelerde Şerh-i akâid olarak kaydedilmiş olup 5 defa geçmektedir.

Akaid kitaplarından Molla Celâl 2 defa, Akayid ve Risale fi'l-Akayid adlı kitaplar da birer defa geçmektedir.

\section{Tablo VII}

Tereke Kayıtlarında Geçen Akaid Eserleri

\begin{tabular}{|l|c|c|}
\hline Eserin Adı & Terekelerdeki Sayısı & Geçtiği Tarih \\
\hline Şerh-i Akâid & 5 & $1092-1102$ \\
\hline Molla Celal & 2 & 1096 \\
\hline Akayid & 1 & 1109 \\
\hline Risale fi'l-Akâyid & 1 & 1096 \\
\hline
\end{tabular}

\section{İlm-i hâl Kitapları}

İlm-i hal kitapları da Osmanlı medreselerinde okutulan kitap türlerinden biridir. 14 terekenin sekizinde bu türden kitaplara rastlanmaktadır. Bunlar arasında adı en sık geçen kitap Risâle-i Birgili' dir. 4 talebe terekesinde geçen bu kitabın adı Risâle-i Birgili, Birgili Risâle ve Birgivî şeklinde farklı şekilde de yazılmaktadir. 
Tablo VIII

Tereke Kayıtlarında Geçen İlm-i Hal Eserleri

\begin{tabular}{|l|c|c|}
\hline Eserin Adı & Terekelerdeki Sayısı & Geçtiği Tarih \\
\hline Risâle-i Birgili (Birgili Risâle, Birgivi) & 4 & $1097-1110$ \\
\hline Tarîkât-1 Muhammediye & 1 & 1097 \\
\hline İksîr-i Devlet & 1 & 1101 \\
\hline Pendname & 1 & 1092 \\
\hline Seyyid Alizâde & 1 & 1103 \\
\hline
\end{tabular}

Terekelerde geçen kitapların diğer ilim dallarına göre dağılımına bakılacak olursa Tefsir alanında (4 kitap) Keşşaf-ı Seydi, Risâle-i Tefsîr, Tefsîr-i Kurtubî, Ebulleys; Tarih alanında (4 kitap) Tuhfetü'l- Mülûk, Ruznâme, Füsul-i Hall-i Akd; Hadis alanında (4 kitap) Cami 'u's-sağir Seyyid, Metn-i Mesabih, Hadis-i Erba în, Metn-i Meşârık; Kelam alanında (3 kitap) Fıkh-ı Ekber, Hâşiye-i Hayâlî, Tevâlî; Tıp alanında (3 kitap) Bukratü't-tıbb?, Cerrah-nâme, Yadigâr-ı ibni Şerif; Tasavvuf alanında (2 kitap) Gojdevânî, Râhâtü'l-Kulûb; Siyer alanında (2 kitap) Siyer-i Ebu'l-feth, Dakâyiku'l-hâkâyık; Arapça eğitiminde (2 kitap) Şerh-i Sekkâki, Karasinan Şerh-i Şâfiye ve Matematik alanında (2 kitap) Eşkâl-i Te sîs, Şerh-i Cezerî gibi kitapların ve Ahlak kitapları olarak İksîr-i Devlet, Pendnâme ve Seyyid Alizâde karşımıza çıkmaktadır.

\section{Kitapların Terekelerde Yer Alma Sıklıklarına ve Fiyatları- na Göre Değerlendirilmesi}

XVII. yüzyıla ait incelenen terekelerde adı geçen kitapların terekelerde yer alma sıklıklarına bakıldığında bunlar arasında öncelikle İbrahim Halebî’nin Mültekâ'l-Ebhur isimli kitabının geldiği görülmektedir. İncelenen 14 terekenin onikisinde adı geçen İbrahim Halebî ya da Mültekâ fikıh alanında en çok müracaat edilen eserdir. Eserin terekelerde geçen fiyatının 100 ile 1100 akçe arasında değiştiği görülmektedir. En düşük fiyattan en yüksek fiyata doğru bir sıralama yapıldığında, 1103 tarihli terekede kaydedilen Mültekâ 100 akçe iken, 1097'de 140, 1099'da kaydedilen iki terekeden ilkinde 155 diğerinde ise 315, 1103'de 400, 1093 ve 1109 tarihlerinde kaydedilen iki terekede 440, 1093'te 480, 1097 'de 500, 1109'da 580, 1092'de 805 akçelik bir fiyat değişimi görülmektedir. 1101 'de ise 1100 akçe olarak kaydedilmiştir. Fiyatlardaki bu farklılık enflasyonun 
yanısıra yazma eser değerini etkileyen faktörler olarak hat, cilt, tezhib gibi yazmayı farklı kılan özelliklerden kaynaklanıyor olmalıdır.

XVII. yüzyıla ait incelenen 14 tereke içerisinde adı ikinci sıklıkta geçen eser ise miras hukuku derslerinde okutulan Ferâiz kitabıdır. Bu eser terekelerde Ferâiz, Metn-i Ferâiz ya da Muhtasar Ferâiz olarak 13 defa geçmektedir. Bu 13 terekenin sekizinde kitaplar müstakil olarak fiyatlandırılmış, bir terekede ise fiyat belirtilmemiştir. Buna göre 1009 tarihli terekede kaydedilen bir Ferâiz kitabının değeri 15 akçe, 1110 'da ise 40 akçe olarak kaydedilmiştir. Diğer Ferâiz kitaplar1 da 1101 'de 105,1097 'de 150,1101 'de 180,1109 'da kaydedilen iki terekenin ilkinde 200, diğerinde 250 ve 1092 tarihli terekede ise 805 akçe olarak değerlendirilip kayda geçirilmiştir.

İncelenen terekelerde adı sık geçen diğer bir eser de ed-Dav 'ale'l-Misbâh isimli eserdir. Bu eser terekelerde kısaca Dav şeklinde kaydedilmektedir. İncelenen 14 terekenin altısında Dav şeklinde, bir tanesinde Nahve müte 'allik Dav şeklinde kaydedilmiştir. 1110 tarihinde kaydedilen Nahve müte 'allik Dav tespit edilen eserlerin içinde 60 akçe ile en düşük fiyata sahiptir. 1097'de kaydedilen Dav 61 akçe, 1109'da 160, 1110'da 180 ve 1092 tarihinde kaydedilenlerden ilki 220, diğer ise 580 akçe olarak fiyatlandırılmıştır.

Molla Câmi terekelerde sık geçen kitaplardan biridir. İncelediğimiz 14 terekenin altısında bu eser kayıtlıdır. Altı eserin dördü Molla Câmi` şeklinde kaydedilirken, bir tanesi Câmî olarak kısaltılmış, bir tanesinin de eksik nüsha olduğu Molla Câmî (Nâkıs) şeklinde belirtilmiştir. 1097 tarihli terekede kayıtlı bulunan bu eksik nüsha Molla Câmî'ye 41 akçe fiyat biçilmiştir. 1110'da kaydedilen diğer bir eserin ise 200 akçe olduğu görülmektedir. Diğer kitaplar ise 1103 'te 220, 1097'de 225, 1109'da 280 ve 1092'de de 655 akçe olarak fiyatlandırılmıştır.

Kurân-1 Kerîm de talebelerin kitapları arasında terekelerde yer almaktadır. Terekelerde Kurân-1 Kerîm için Kelâm-ı Kadîm, Kelâmullah, Mushâf-ı Şerîf ifadeleri kullanıldığı görülmektedir. 14 terekenin beşinde Kurân-1 Kerîm olduğu tespit edilmiştir. Bunların terekelerde fiyatlandırılmasına bakılacak olursa 1109 tarihli terekede 500 akçe, 1101 tarihli terekede 600 akçe, 1097'de 1500 ve 1103'de 2151 ve 1092 tarihli terekede ise 3000 akçe ile fiyatlandırılmıştır.

Medreselerde okutulan kitaplar arasında Birgivî diye bilinen Mehmed Efendi'ye aid Risâle de sıkça görülmektedir. Bu kitabın ismi terekelerde Birgili 
Risâle, Risâle-i Birgili, Birgivî şeklinde üç farklı şekilde yazılmıştır. İncelenen 14 terekenin dördünde kayıtlı bulunan bu eserin fiyatlarına bakılacak olursa 1097 tarihli terekede 50 akçe olarak, 1110 'da 60 ve 1103 tarihinde 65 akçe olarak fiyatlandırılmıştır. 1097 tarihli başka bir terekede geçen eserin ise 220 akçe olarak değerlendirildiği görülmektedir.

14 terekenin dördünde kayıtlı bulunan diğer bir eser de İftitâh'tır. Bu eserin fiyatı yakın tarihlerde farklılık göstermektedir. İlk defa 1097 tarihli terekede görülen Iftitâh 50 akçe olarak fiyatlandırılmıştır. Bununla birlikte 1097 tarihli başka bir terekede 80,1110 'da 80,1109 'da ise 130 akçe olarak değerlendirilmiştir.

14 terekenin dördünde geçen eserlerden biri de Sarf olarak kaydedilen gramer kitabıdır. Bunlardan 1103 tarihli terekede geçen kitap 40 akçe olarak kaydedilirken 1097 tarihli terekede 77 akçe olarak değer bulmuştur. Diğer iki sarf kitabı ise 1109 'da 100 ve 1097 'de 105 akçe olarak fiyatlandırılmıştır.

Şâhidî olarak kaydedilen eser de dört terekede mevcut olup 1103'te 25, 1109'da 40, 1101'de 65 ve 1109 tarihinde ise 160 akçe olarak değerlendirilmiştir.

Terekelerde adı birden fazla geçen eserlerden biri de Eşbâh ve Nezâyir' dir. 14 terekenin üçünde bulunan bu eserin fiyatı 1092 tarihli terekede kaydedilmemiştir. 1097 tarihli iki terekenin birinde 199 diğerinde ise 500 akçe olarak değerlendirilmiştir.

Sadru'ş-şeri ' $a$ isimli eser de 14 terekenin üçünde kayıtlıdır. 1109 ve 1097 tarihli terekelerde geçen iki eser 300 akçe olarak değer bulmuşken 1092 tarihli terekede 715 akçe olarak fiyatlandırılmıştır. 


\section{Terekelerin Transkripsiyonları}

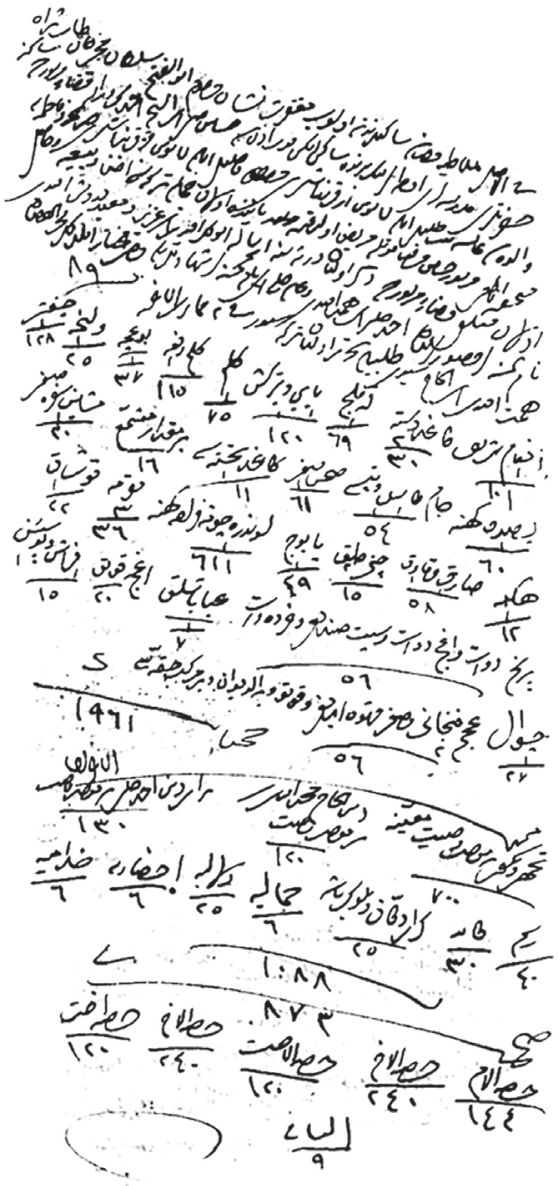

2 Cemaziyelâhir 1089

(Mülga Beledî Kassamlığı, 12, 93a)

Fi'l-asl Malatya kazâs1 sâkinlerinden olup mağfiret-nişân merhûm Ebu'lFeth Sultan Mehmed Hân -tâbe serâh- hazretleri medreseleri odalarının birinde sâkin iken fevt olan Hüseyin Çelebi ibn-i eş-Şeyh Ahmed'in verâseti kazâ-i 
mezbûrda sâkine vâlidesi Aişe binti Tayyib? ile li-ebeveyn er karındaşları Mustafa ve Halil ile li-ebeveyn kız karındaşları Hadice ve Fatıma’ya munhasıra olmağın mezbûr Hüseyin maraz-1 mevtle marîz oldukda yanında olan hüccetle terekesini ahz ve bey'a ve hâsıl olan meblağı kazâ-i mezbûrda zikr olunan veresesine irsâle Ebubekir Efendi b. Aziz ve Muid Derviş Efendi nâm kimesneler huzûrlarında Ahmed Çelebi ibn-i Himmet Efendi ve Ali Çelebi nâm kimesneler şehâdetleriyle vasiyy-i muhtâr eyledikleri fahrü'l-kudât Himmet Efendi ibn-i el-Hâc Seydi talebiyle tahrîr olunan terekesidir. Fî 2 Cemaziyelâhir sene [10]89.

En'âm-1 şerîf

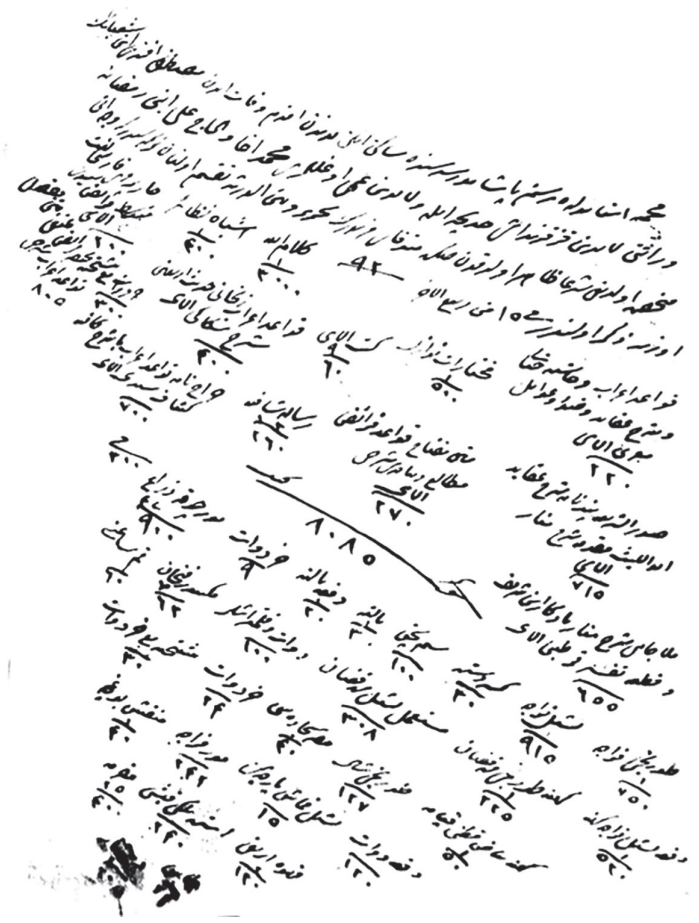

15 Rebiulâhir 1092

(İstanbul ŞS, TSMA, 242, 18) 
Mahmiye-i İstanbul'da Rüstem Paşa Medresesi'nde sâkin iken bundan akdem vefat eden Mustafa Efendi b. Şaban'ın veraseti li-ebeveyn kız karındaşı Hadice ile li-ebeveyn ammi oğulları Mehmed Ağa ve el-Hâc Ali ibn-i Ramazan'a munhasıra olduğu şeran zahir oldukdan sonra müteveffâ-yı mezbûrun tahrîr ve beyne'l-verese taksim olunan terekesidir ki vech-i âtî üzere zikr olunur. Fi'lyevmi'l-hadi ve'l-1̧̧rin mine'l-Muharremi'l-haram sene 1128.

\begin{tabular}{|l|c|}
\hline Kitap Adı & Fiyatı \\
\hline Kelamullah & 3000 \\
\hline Eşbâh [ve] Nezâyir & 400 \\
\hline Çarperdi, Farisî lügat, Mutavassıt ve Ferâiz-i Seydi alayı & 200 \\
\hline $\begin{array}{l}\text { Kavaid-i İrab ve Hâşiye-i Hayali ve Şerh-i Akâid ve Dav ve } \\
\text { Avâmil-i Mu'ribî alayı }\end{array}$ & 220 \\
\hline Muhtarat-1 Nevazil & 500 \\
\hline Kütüb alayı & 60 \\
\hline Kavaid-i İrab-1 Zencani, Hadis-i Erba‘în, Şerh-i Sekkaki alayı & 400 \\
\hline Hırdavat maa piştahta & 300 \\
\hline Muhtasar Ferâiz, Mültekâ metni mufassal, Kavaid-i İrab Şerhi & 805 \\
\hline $\begin{array}{l}\text { Sadrü'ş-Şeria, Pendname, Şerh-i Akâid, Ebulleys, Mukaddi- } \\
\text { me, Şerh-i Menar alayı }\end{array}$ & 715 \\
\hline Metn-i Miftah, Kavaid-i Ferâiz, Metali Dibacesi Şerhi & 270 \\
\hline Risale-i Şafiye & 260 \\
\hline $\begin{array}{l}\text { Harac-name/Cerrah-name, Kavaid-i İrab ba-şerh-i Kâfiye, } \\
\text { Keşşaf-1 Seydi, alayı }\end{array}$ & 700 \\
\hline $\begin{array}{l}\text { Molla Cami, Şerh-i Menar, Yadigar-1 ibni Şerif ve kıta Tefsir-i } \\
\text { Kurtubi, alayı }\end{array}$ & 655 \\
\hline Yekûn-1 kütüb & 8085 \\
\hline
\end{tabular}



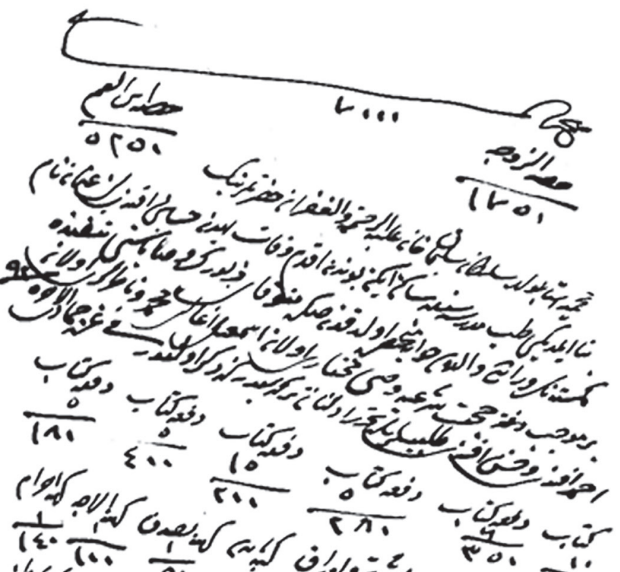

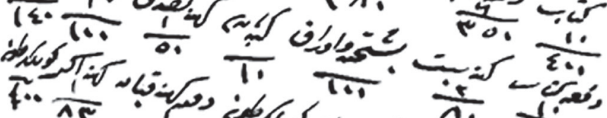

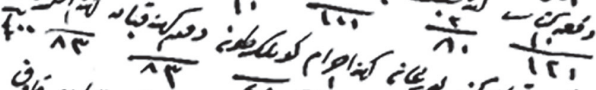
र्व

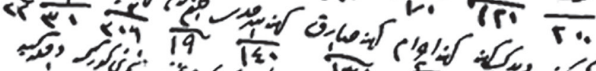

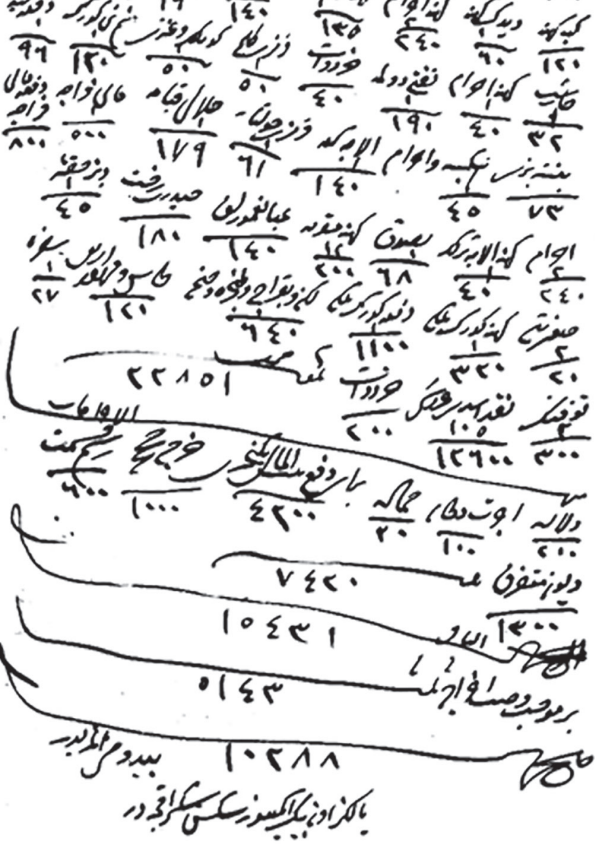


1 Cemaziyelâhir 1092

(Mülga Beledî Kassamlığı, 15, 17a)

Mahmiye-i İstanbul'da Sultan Süleyman Han aleyhi'r-rahmeti ve'l-gufran hazretlerinin bina eylediği Tıp medresesinde sâkin iken bundan akdem vefât eden Hüseyin Efendi bin Osman nâm kimesnenin verâseti vâlidesi Havva'ya münhas1ra olduktan sonra müteveffâ-yı mezbûrun vesâyasını tenfîze ber-mûceb-i hüccet-i şer'iyye vasiyy-i muhtârı olan İsmail Ağa bin Mehmed ve nâzırları olan Ahmed Efendi ve Hasan Efendi talebleriyle tahrîr olunan terekesidir ki zikr olunur. Fî Gurre-i Cemaziye'l-âhire sene 1092.

Not: Kitap adları kaydedilmemiştir.

\begin{tabular}{|l|c|c|}
\hline Kitab Adı & Adedi & Fiyatı \\
\hline Kitab & 10 & 400 \\
\hline Defa Kitab & 6 & 350 \\
\hline Defa Kitab & 5 & 280 \\
\hline Defa Kitab & 15 & 200 \\
\hline Defa Kitab & 5 & 400 \\
\hline Defa Kitab & 5 & 180 \\
\hline Defa Kitab & 10 & 121 \\
\hline Piştahta ve evrâk & & 100 \\
\hline
\end{tabular}


4

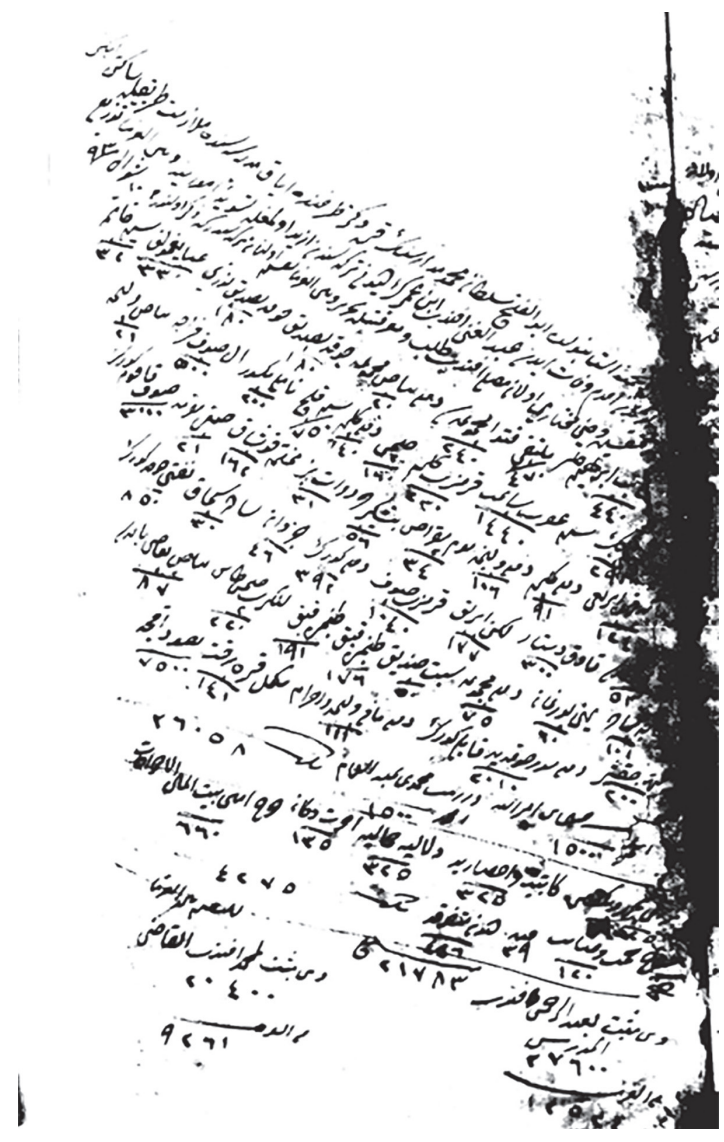

10 Şevvâl 1093

(İstanbul Ş.S. (TSMA), 243, vr.7)

Mahmiye-i İstanbul'da Ebu'l-feth Sultan Mehmed medârisinin Karadeniz tarafında Ayak medresesinde mülâzemet tarîkiyle sâkin iken bundan akdem vefât eden Abdülganî Efendi ibn-i Ömer'in deyni terekesinden ezyed olmağla tesviye-i emvâline ve beyne'l-guremâ tevzî‘ ve taksîmine vasiyy-i muhtârı olan Musli Efendi taleb ve ma'rifetiyle tahrîr ve beyne'l-guremâ taksîm olunan terekesidir ki zikr olunur. Fî 10 Şevvâl 1093. 


\begin{tabular}{|l|c|}
\hline Kitap Adı & Fiyatı \\
\hline İbrahim Halebî & 440 \\
\hline Mültekâ & 480 \\
\hline Fetvâ mecmuası & 240 \\
\hline Def'a beyaz mecmu'a & 20 \\
\hline
\end{tabular}

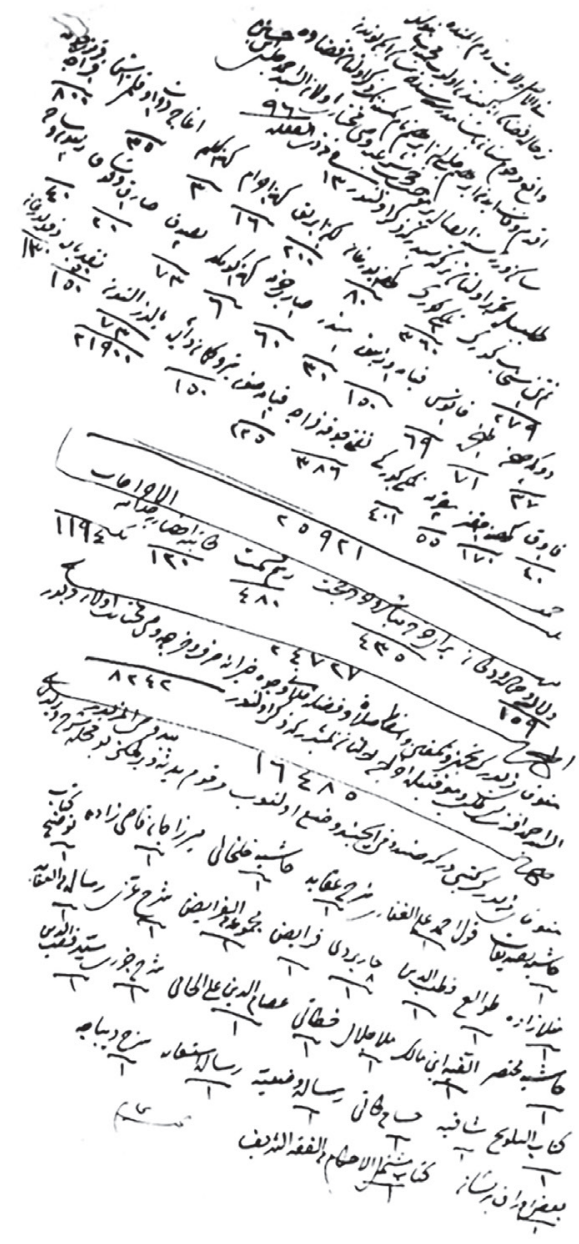




\section{5}

13 Zilkade 1096

(Mülga Beledî Kassamlığı, 18, 93b)

Fi'l-asl vilâyet-i Rumelinde Tirhala kazâsı ahâlîsinden olup mahmiye-i İstanbul'da vaki merhûm Sinan Paşa Medresesi'nde sâkin iken bundan akdem vefât eden İbrahim Çelebi ibn-i İbrahim nâm kimesnenin zikr olunan kazada sâkin veresesine isâle ber-mûceb-i hüccet-i şeriyye vasiyy-i muhtârı olan es-Seyyid Ahmed Çelebi ibn-i Hüseyin talebiyle tahrîr olunan terekesidir ki zikr olunur. Fî 13 Zilkade sene (10)96.

Müteveffâ-yı mezbûrun kütübüdür ki sanduğı içinde vaz olunup merkum yedine virilmeğin bu mahalle şerh virildi.

Not: Fiyatları kaydedilmemiştir.

\begin{tabular}{|l|c|}
\hline Kitap Adı & Adedi \\
\hline Hâşiye-i Tasdikat & 1 \\
\hline Kul Ahmed ale'l-Fenari & 1 \\
\hline Şerh-i Akâid & 1 \\
\hline Hâşiye-i Halhali & 1 \\
\hline Mirzacan Kadızade & 1 \\
\hline Kitab-1 Tavzih & 1 \\
\hline Monlazade & 1 \\
\hline Tevali & 1 \\
\hline Kutbuddin & 1 \\
\hline Çarperdi & 1 \\
\hline Ferâiz & 1 \\
\hline Mecmua ani'l-Ferâiz & 1 \\
\hline Şerh-i İzzî & 1 \\
\hline Risale fi'l-Akayid & 1 \\
\hline Hâşiye-i Muhtasar & 1 \\
\hline Elfiyye-i İbn-i Malik & 1 \\
\hline Molla Celal & 1 \\
\hline Hitati & 1 \\
\hline Isamüddin ale'l-Cami & 1 \\
\hline Şerh-i Cezeri & \\
\hline
\end{tabular}


Ekrem TAK, Bilgin AYDIN, XVII. Yüzyılda İstanbul Medreselerinde Okutulan Kitaplar (Tereke Kayıtları Üzerine Bir Değerlendirme)

\begin{tabular}{|l|c|}
\hline Seyyid Kutbüddin & 1 \\
\hline Kitabü't-Telvih & 1 \\
\hline Şafiye & 1 \\
\hline Hüssam-1 Kati & 1 \\
\hline Risale-i Vaziyye? & 1 \\
\hline Risale-i İstiare & 1 \\
\hline Şerh-i Dibâce & 1 \\
\hline Bazı Evrâk-1 perîşân & 1 \\
\hline Kitabu Müştemilü'l-Ahkam fi'l-Fıkhi'ş-Şerif & 1 \\
\hline
\end{tabular}

6

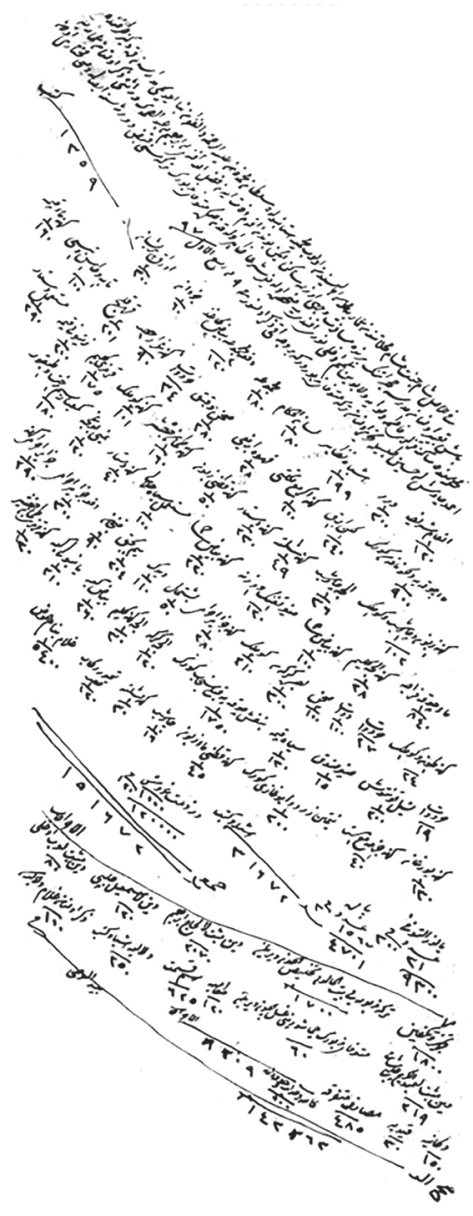




\section{6}

9 Rebiulevvel sene 1097

(K1smet-i Askeriye, 12, 57a)

Fi'l-asl Şâm-1 cennet-meşâm mahallâtından Ammâriye mahallesi ahâlîsinden olup mahmiye-i İstanbul'da Sultan Mehmed aleyhi'r-rahmeti ve'lgufrân binâ eylediği medârisden Karadeniz tarafında baş ta'bîr olunan medrese hucurâtının birinde müsâferet vechi üzere sâkin iken bundan akdem vefât eden Fazlullah Efendi b. İbrahim b. Abdüssamed'in verâseti zikr olunan Ammâriye mahallesinde sâkine kızları Fatıma ve Havva'ya ve li-ebeveyn ammî oğlu Nuri Efendi'ye münhasıra olduğu şer'an zâhir oldukdan sonra müteveffâ-y1 mezbûrun terekesini kabz ve veresesine îsâle vasiyy-i muhtâr olan Ahmed Çavuş bin Hüseyin talebi ile tahrîr olunan tereke-i müteveffâ-yı mezbûrdur ki ber-vech-i âti zikr olunur. Fî 9 min Rebi‘u'l-evvel sene [10]97.

\begin{tabular}{|l|c|c|}
\hline Kitap Adı & Adedi & Fiyatı \\
\hline En‘âm-1 Şerîf & 1 & 120 \\
\hline Dürer & 1 & 300 \\
\hline Eşbâh-1 Nezâyir & 1 & 199 \\
\hline Lisânü’l-Hükkâm & 1 & 180 \\
\hline Mecmu'a & 1 & 180 \\
\hline Def‘a Mecmu'a, beyaz kağıt & 2 & 120 \\
\hline Evrâk-1 perîşân & 3 & 200 \\
\hline Yekûnküitüb & & $\mathbf{1 3 5 9}$ \\
\hline
\end{tabular}



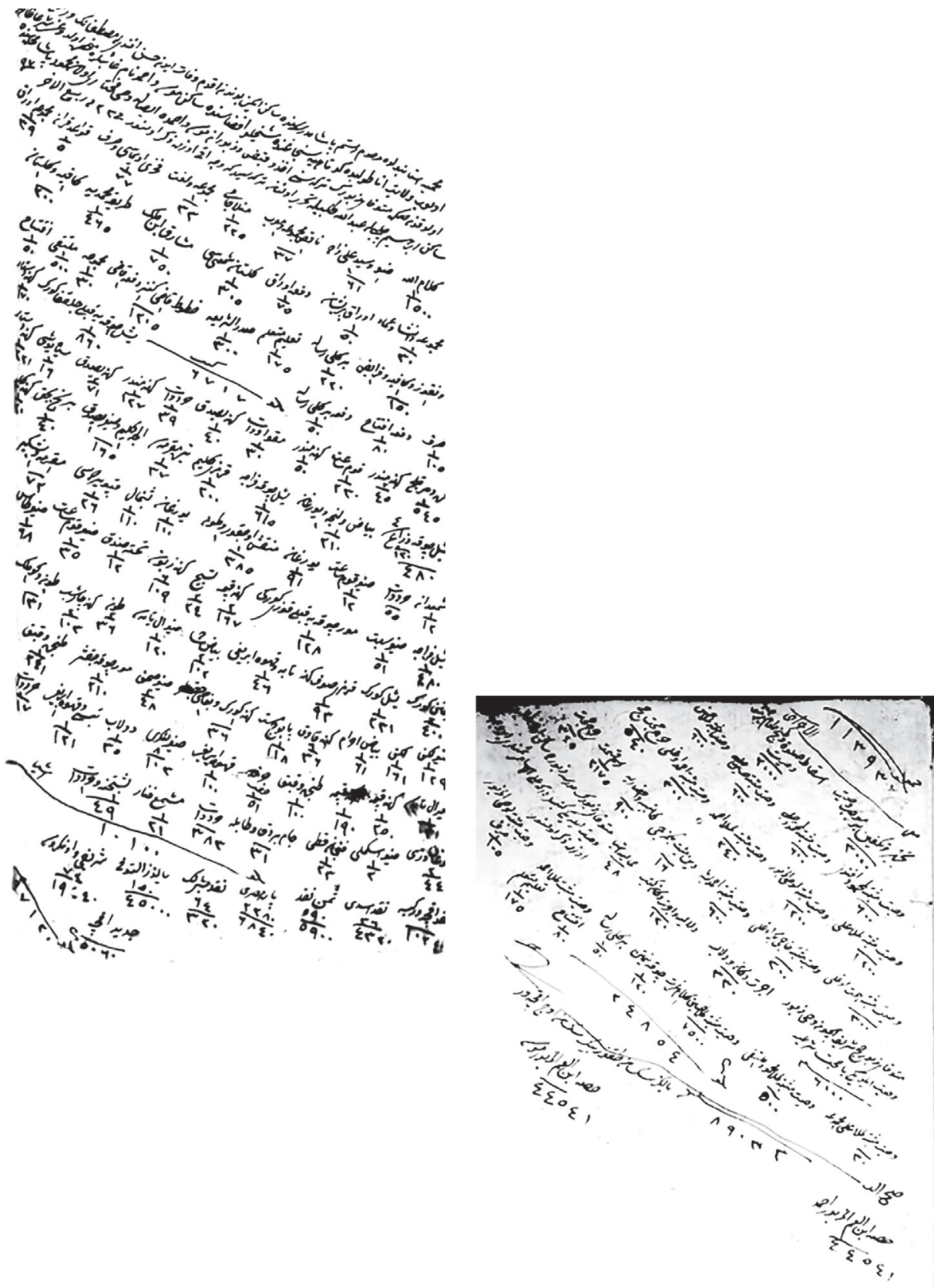
23 Rebiulahir 1097

(K1smet-i Askeriye, 12, 110b-11a)

Mahmiye-i İstanbul'da merhûm Rüstem Paşa Medresesi’nde sâkin iken bundan akdem vefât eden Hasan Efendi bin Mustafa'nın verâseti li-ebeveyn ammî oğulları olup Vilâyet-i Anadolu'da Kütahya sancağında Şeyhlü kazâsında sâkin Musa ve Ahmed nâm gâiblere münhasıra olduğu şer'an zâhir oldukdan sonra müteveffâ-yı mezbûrun terekesini ahz ve kabz ve mezbûrân Musa ve Ahmed'e îsâle dahi vasiyy-i muhtâr olan Mahmud Paşa mahallesinde sâkin İbrahim Çelebi bin Abdullah talebiyle tahrîr olunan terekesidir ki vech-i âti üzere zikr olunur. Fî 23 min Reb'u'l-âhir sene [10]97.

\begin{tabular}{|l|c|c|}
\hline Kitap Adı & Adedi & Fiyatı \\
\hline Kelâmullah & 1 & 1500 \\
\hline Dav ve Seyyid Ali-zâde & 1 & 61 \\
\hline Nâkıs mecmu'a ve Mu'rib & 1 & 37 \\
\hline Molla Câmî & 1 & 225 \\
\hline Mecmu'a ve Lugat & 1 & 33 \\
\hline Fahri ed'iyası? ve Sarf & 1 & 77 \\
\hline Kavâ'id-i Kurân & 1 & 5 \\
\hline Mecmu'a evrak & 1 & 39 \\
\hline Mecmu'a ve İnşâ ve İmâd & 1 & 30 \\
\hline Evrâk-1 perişân & 1 & 50 \\
\hline Def'a evrak & 1 & 75 \\
\hline Gülistân Şem'îsi? & 1 & 305 \\
\hline Meşârık-1 İbn-i Melek & 1 & 750 \\
\hline Tarîkât-1 Muhammediye & 1 & 465 \\
\hline Kâfiye ve Gülistân & 1 & 200 \\
\hline Dinkoz ve Kâfiye ve Ferâiz & 1 & 150 \\
\hline Birgili Risâle & 1 & 220 \\
\hline Ta'lîm-i müte'allim & 1 & 175 \\
\hline Sadru'ş-şeri'a & 1 & 300 \\
\hline Hutût-1 Kadı & 1 & 1205 \\
\hline Kenz & 1 & \\
\hline Def'a Kadı & 1 & \\
\hline
\end{tabular}




\begin{tabular}{|l|c|c|}
\hline Mecmu'a & 1 & 30 \\
\hline Mültekâ & 1 & 500 \\
\hline İftitâh & 1 & 50 \\
\hline Sarf & 1 & 105 \\
\hline Def'a İftitâh & 1 & 80 \\
\hline Def'a Birgili Risâle & 1 & 50 \\
\hline Yekûn küiüb & & $\mathbf{6 7 1 7}$ \\
\hline
\end{tabular}

8

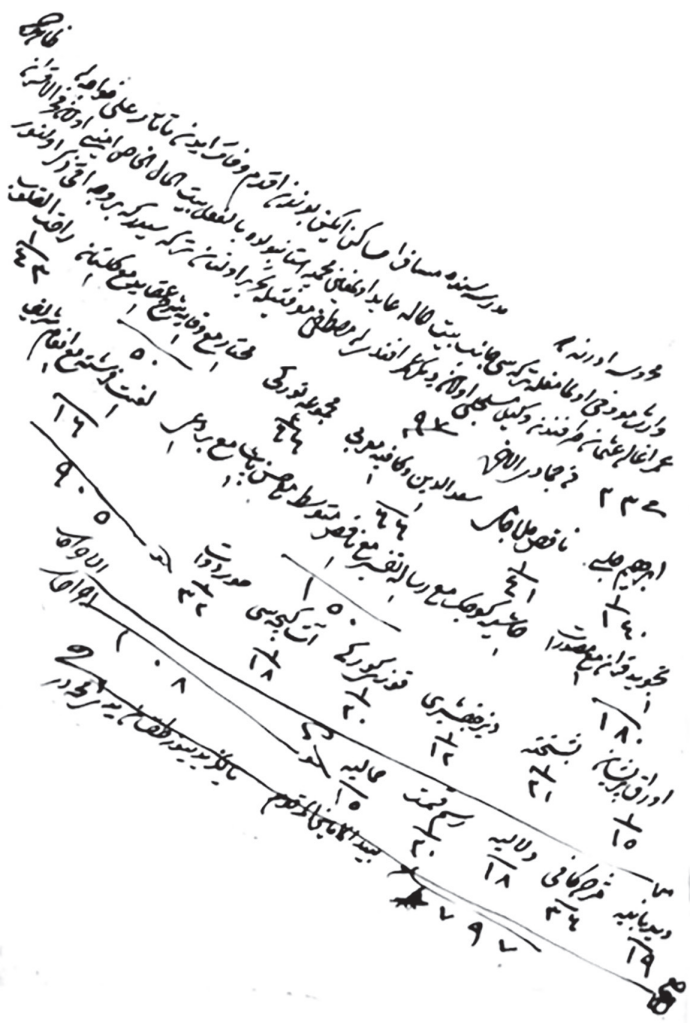

8

23 Cemaziyelâhir 1097

(Kismet-i Askeriye, 12, 188a)

Mahrûse-i Edirne'de (boş) medresesinde misâfiren sâkin iken bundan ak- 
dem vefât iden Tatar Ali hoca bin (boş) zâhirde vâris-i ma'rûfu olmamakla terekesi cânib-i beytü'l-mâle âit olmağın mahmiye-i İstanbul' da bi'l-fi'‘il beytü'l-mâli'lhâs emini olan fahrü'l-akrân Ömer Ağa bin Osman tarafından vekîl-i müsecceli olan diğer Ömer Efendi bin Mustafa ma'rifetiyle tahrîr olunan terekesidir ki bervech-i âti zikr olunur. Fî 23 min Cemâziye'l-âhir sene [10]97.

\begin{tabular}{|l|c|c|}
\hline Kitap Adı & Adedi & Fiyatı \\
\hline İbrahim Halebî & 1 & 140 \\
\hline Nâkıs Molla Câmî & 1 & 41 \\
\hline Sâdeddin ve Kâfiye-i Mu'ribî & 1 & 66 \\
\hline Mecmu'a-i Türkî & 2 & 44 \\
\hline Muhtâr ma'a Vikâye Şerh-i akâid ma'a Gülistân & 1 & 50 \\
\hline Râhâtü'l-Kulûb & 1 & 43 \\
\hline Tecvîd-i Kurân ma'a Musavverât & 1 & 180 \\
\hline $\begin{array}{l}\text { Hâşiye-i Küçük ma'a Risâle-i Tefsîr ma'a nâkıs Mutavas- } \\
\text { sit ma'a Hasan Paşa ma'a Berdaî }\end{array}$ & 1 & 150 \\
\hline Lugât-i Ferişte ma'a En'âm-1 Şerîf & 1 & 16 \\
\hline Evrâk-1 Perîşân & 1 & 15 \\
\hline Pîş tahta & $\mathbf{1}$ & $\mathbf{2 1}$ \\
\hline
\end{tabular}



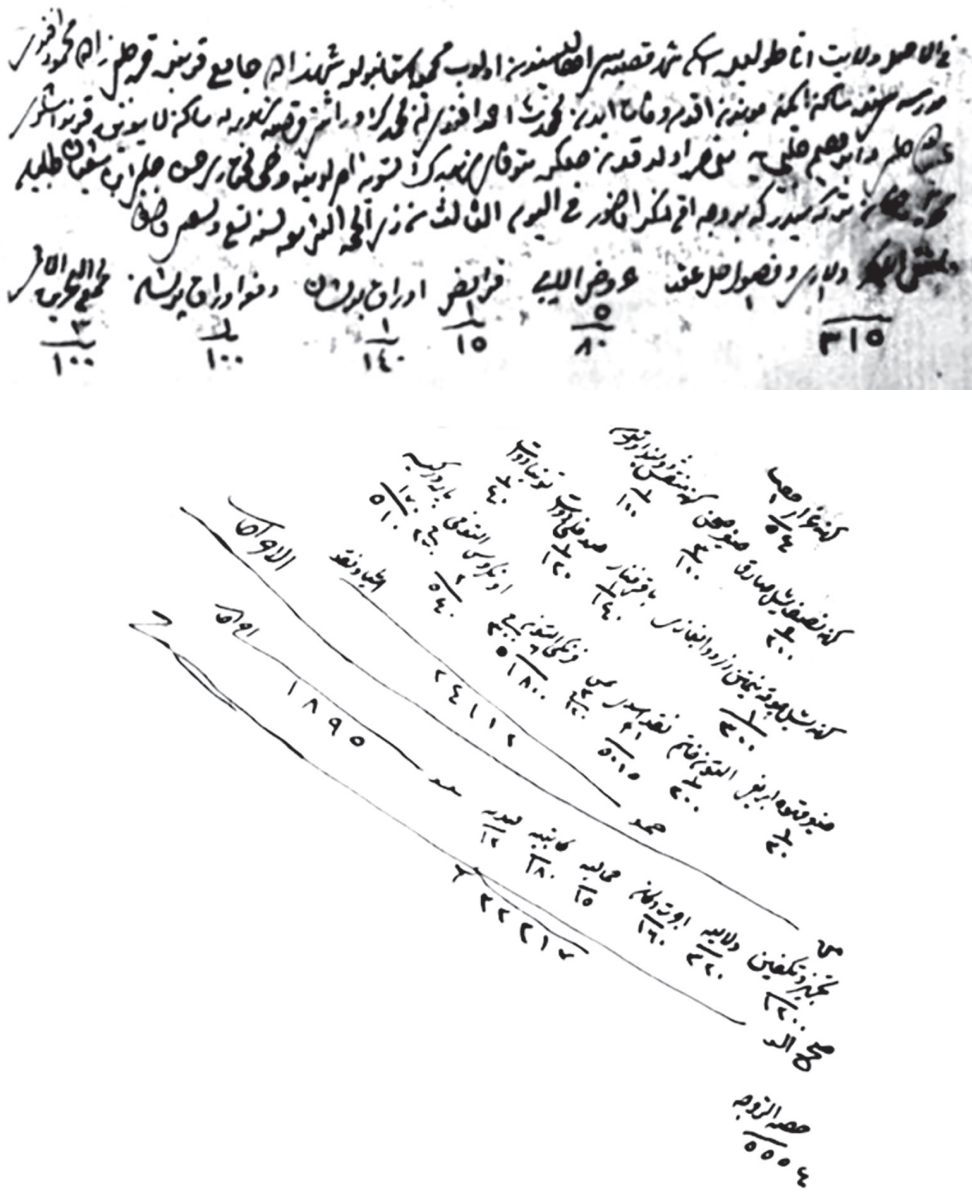

9

9 Receb 1097

(Kısmet-i Askeriye, 12, 137b-138a)

Fi'l-asl vilâyet-i Anadolu'da Ankara ahâlîsinden olup mahmiye-i İstanbul'da Süleymâniye medresesinin birinde müsâferet vechi üzere sâkin iken vefât eden es-Seyyid Kasım Efendi bin İsmail bin Kasım'ın verâseti zevce-i menkûha-i metrûkesi Emetullah binti el-Hâc Mehmet ile babası mezbûr İsmail 
Efendi'ye münhasıra olduğu şer'an zâhir oldukdan sonra müteveffâ-yı mezbûrun tahrîr ve beyne'l-verese taksîm olunan terekesidir ki ber-vech-i âti zikr olunur. Fî 9 min Receb sene [10]97.

\begin{tabular}{|l|c|c|}
\hline Kitap Adı & Adedi & Fiyatı \\
\hline Eşbâh-1 Nezâyir & 1 & 500 \\
\hline Câmi'u'l-Fetâvâ & 1 & 120 \\
\hline Şerh-i Kudûrî & 1 & 200 \\
\hline Beyaz Mecmu'a & 2 & 100 \\
\hline Eczâ-i Hidâye & 18 & 200 \\
\hline
\end{tabular}

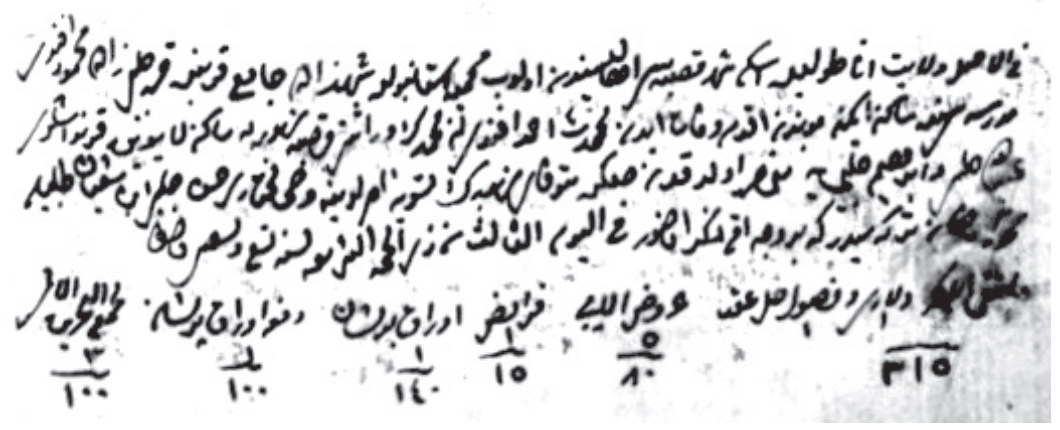

3 Zilhicce 1099

(Kismet-i Askeriye, 13, 27b-28a)

Fi'l-asl vilâyet-i Anadolu'da Eskişehir kasabası ahâlîsinden olup mahmiye-i İstanbul'da Şehzâde cami'i kurbunda Karaçelebizâde Mahmud Efendi Medresesi'nde sâkin iken bundan akdem vefât eden Mehmed bin Ahmed Efendi bin Mehmed'in verâseti kasaba-i mezbûrede sâkin li-ebeveyn karındaşları Abdullah Çelebi ve İbrahim Çelebi'ye münhasıra oldukdan sonra müteveffâ-yı mezbûrun tesviye-i emirlerine vasiyy-i muhtârları Hasan Çelebi b. Şaban talebiyle tahrîr olunan terekesidir ki ber-vech-i âti zikr olunur. Fi'l-yevmi's-sâlis min Zilhicceti'ş-şerîfe li sene tis'â ve tis'în ve elf. [3 Zilhicce 1099] 


\begin{tabular}{|l|c|c|}
\hline Kitap Adı & Adedi & Fiyatı \\
\hline Mültekâ [Ebhur] ve Lârî ve Füsul-i Hall-i Akd & 1 & 315 \\
\hline Arûz alayı & 5 & 80 \\
\hline Ferâiz & 1 & 15 \\
\hline Evrâk-1 Perîşân & 1 & 140 \\
\hline Def'a Evrâk-1 Perîşân & 1 & 100 \\
\hline Mecma'u'l-Bahreyn alayı & 3 & 100 \\
\hline $\begin{array}{l}\text { Kazımir ve metn-i Bukratü't-tıbb/tayyib? ve Karasinan Şerh-i } \\
\text { Şâfiye ve Şerh-i Kaside-i Bürde }\end{array}$ & 1 & 170 \\
\hline Cevâmi'-i Ezheriye alayı & 2 & 80 \\
\hline Mültekâ'l-ebhûr cüzleri & 1 & 155 \\
\hline
\end{tabular}




\section{1}
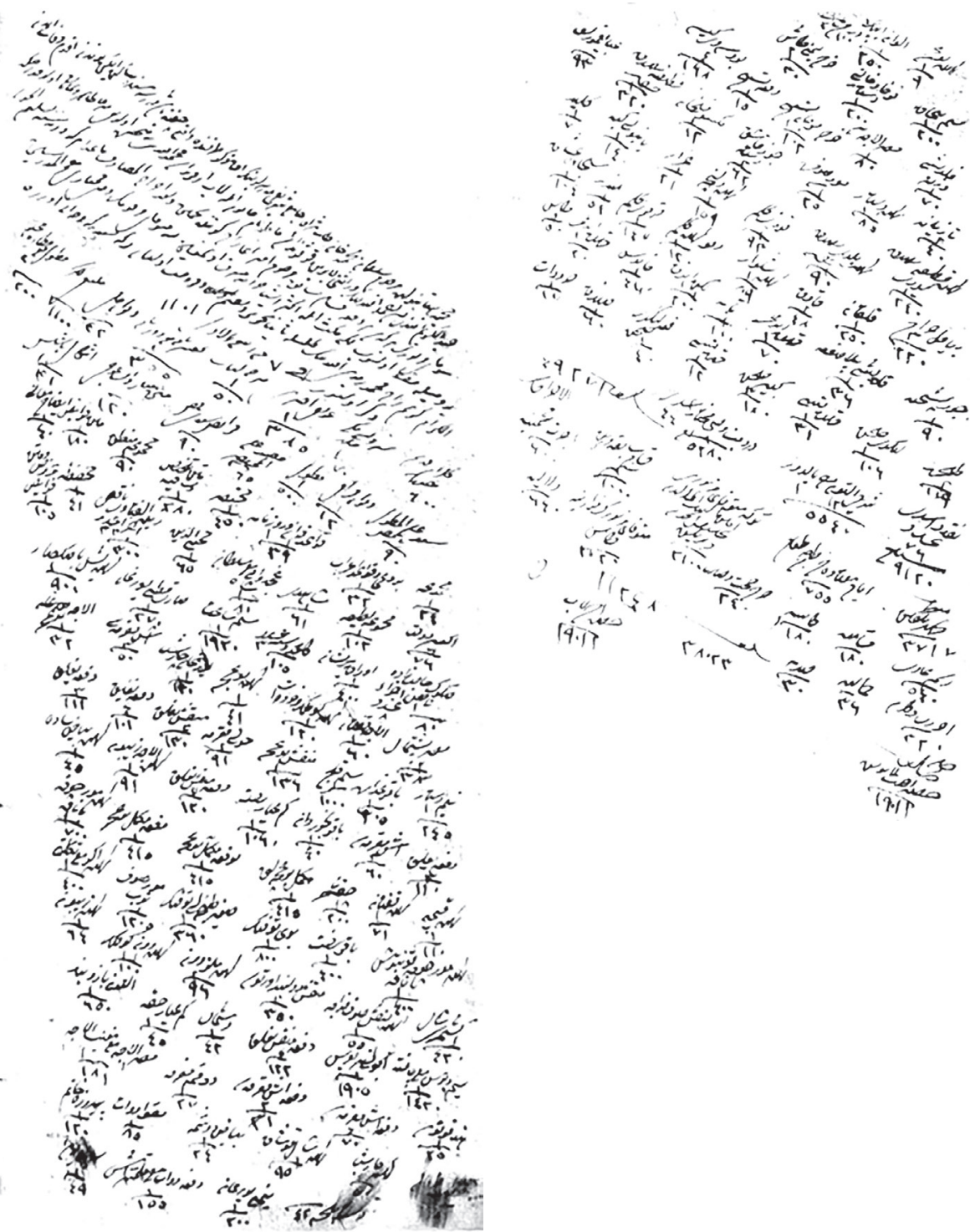


\section{1}

7 Rebiulevvel 1101

(K1smet-i Askeriye, 16, 6b-7a)

Mahmiye-i İstanbul'da merhûm Sultan Mehmed hân tâbe-serâh câmi'-i şerîfi medreselerinin Akdeniz tarafında vâki c çifte baş medresesinde sâkin iken bundan akdem vefât eden Abdulkerim Efendi bin Ahmed Efendi'nin verâseti liebeveyn kız karındaşı Fatıma nâm hâtun ile li-eb er karındaşı Mehmed Efendi’ye münhasıra olduğu şer`an zâhir ve nümâyân oldukdan sonra müteveffâ-yı mezbûrun terekesi bir def'a kassâm-1 sâbık merhûm Emir Ağazâde gününde tahvîn ve ba 'de ihrâci'l-masârif ma'adâsı ki veresesine teslim içün ........... olunup lâkin meks ile ekser eşya harâbe müşrif olmağın yine müteveffâ-yı merkûmun vasiyy-i muhtârı fahrü'l-müderrisîni’l-kirâm Kerimzâde Mehmed Remzi? Efendi’nin talebiyle ...? tahrîr ve taksîm ve füruht olunan terekesidir ki vech-i âti üzere zikr olunur. Fî 7 min Rebi'u'l-evvel sene 1101.

\begin{tabular}{|l|c|c|}
\hline Kitap Adı & Adedi & Fiyatı \\
\hline Kelâm-1 Kadîm & Cild 1 & 600 \\
\hline Sürûri-i/Şezûli-i Mekkî & Cild 1 & 70 \\
\hline Avâmil? Ahterî & 1 & 385 \\
\hline Şerh-i Lübâb & 1 & 50 \\
\hline Ta‘bîrnâme ma'a Ruznâme & 1 & 355 \\
\hline Dîvân-1 Câmî & & 42 \\
\hline Mültekâ'l-Ebhur & 1 & 1100 \\
\hline Mutavvel ma'a ....... & 2 & 200 \\
\hline Seyyid ale'l-mutavvel nâkıs & 1 & 90 \\
\hline Dîvân-1 Merâkî & 1 & 12 \\
\hline Mutavvel & & 500 \\
\hline Müfid/Mukayyid ale'l-muhtasar & & 65 \\
\hline Ferâiz-i Seydî nâkıs & & 90 \\
\hline Metn-i Menâr ve İsagoci & 1 & 120 \\
\hline Eşkâl-i Te'sîs & 1 & 41 \\
\hline Mecmu'a & 1 & 24 \\
\hline Berzenci? ve Kavâ‘id-i İ'râb & & 32 \\
\hline Kavâ‘id-i Kurân ve Ruznâme & & 39 \\
\hline
\end{tabular}




\begin{tabular}{|l|c|c|}
\hline Muhtasar & 1 & 450 \\
\hline Metn-i Telhîs ve Şâfiye & 1 & 280 \\
\hline Mecmu'a-i Mantık & 1 & 90 \\
\hline Metn-i Ferâiz & 1 & 180 \\
\hline İzâh-1 Me‘ânî & 1 & 40 \\
\hline İksîr-i Devlet & 6 & 76 \\
\hline Mecmu'a-i Latîfe & 1 & 102 \\
\hline Şâhidî & 1 & 65 \\
\hline Gojdevânî ma'a Sultanşah & 1 & 81 \\
\hline Muhyiddin & 1 & 65 \\
\hline Zübdetü’l-Fetâvâ nâk1s âhir & 23 & 300 \\
\hline Arûz ve Metn-i Ferâiz & 1 & 105 \\
\hline Sükûk-1 Hâcibzâde nâkıs eczâ & 8 & 80 \\
\hline Evrâk-1 Perîşân & 1 & 400 \\
\hline
\end{tabular}




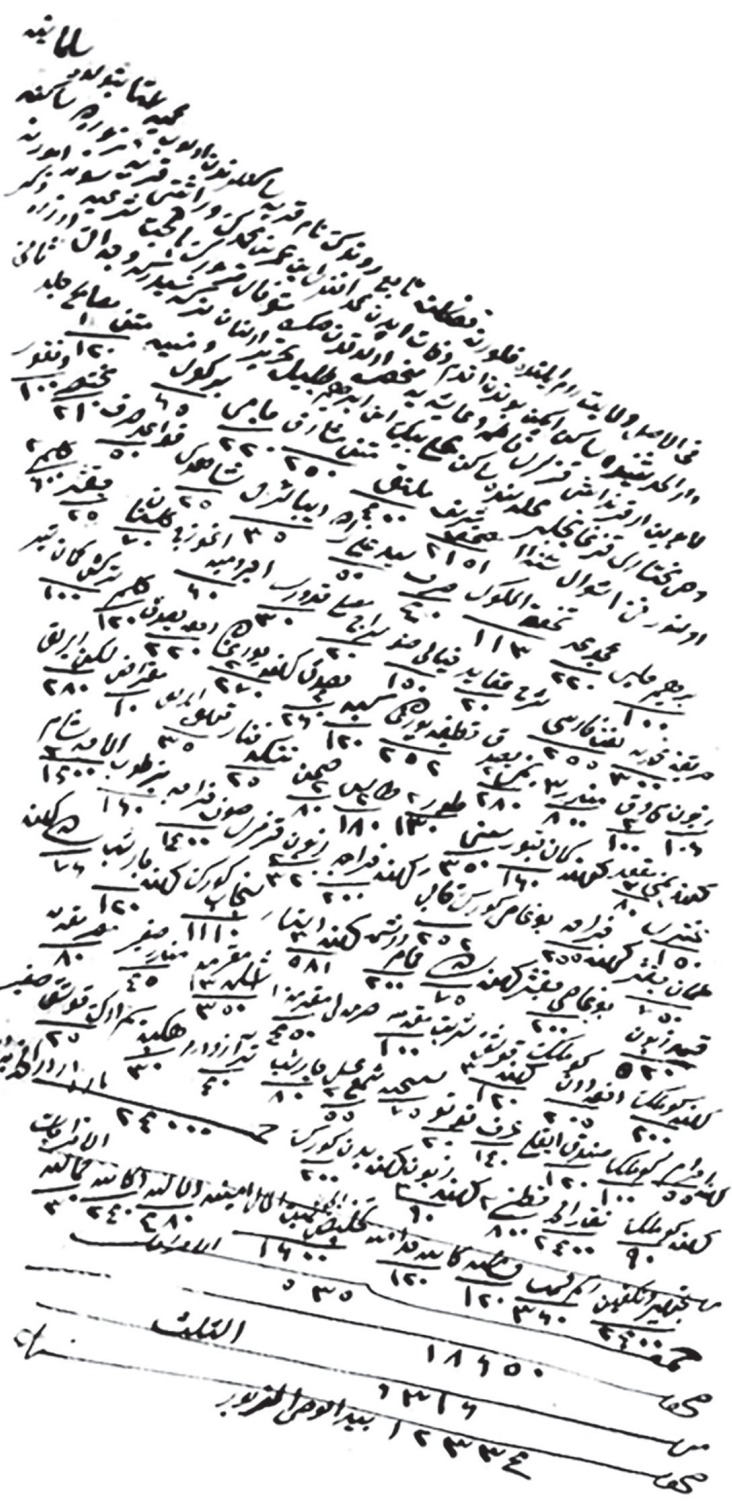


10 Şevval 1103

(İstanbul ŞS, TSMA, 264, 6a)

Fi'l-asl vilâyet-i Rumelinde Filorina kazasına tabi Revendik/Rondik nâm karye sâkinlerinden olup mahmiye-i İstanbul'da Süleymaniye Dârü'l-hadîsi'nde sâkin iken bundan akdem vefât eden Mehmed Efendi b. Ömer b. Mehmed'in veraseti karye-i mezbûrede sâkineli-ebeveyn er karındaşı kızları Fatıma ve Aişe'ye münhasıra oldukdan sonra müteveffâ-yı mezbûrun ba-hüccet-i şeriyye tesviye-i umuruna vasiyy-i muhtarı Kazgancılar Mahallesinde sâkin Ali Beğ b. İbrahim talebiyle tahrîr olunan terekesidirki vech-i âti üzere zikr olunur. Fî 10 Şevval sene 1103.

\begin{tabular}{|l|c|}
\hline Kitap Adı & Fiyatı \\
\hline Mushaf-1 Şerif & 2151 \\
\hline Mültekâ & 400 \\
\hline Metn-i Meşarık & 250 \\
\hline Câmî & 220 \\
\hline Birgivi ve Münye & 65 \\
\hline Metn-i Mesabih cild-i sani & 120 \\
\hline İbrahim Halebî & 100 \\
\hline Mecmua & 220 \\
\hline Tuhfetü'l- Müluk & 113 \\
\hline Sarf & 40 \\
\hline Seyyid Alizade & 50 \\
\hline Diba[ce] şerhi & 35 \\
\hline Şâhidî & 25 \\
\hline Kavaid-i Sarf & 50 \\
\hline Muhtasar & 21 \\
\hline Dinkoz & 100 \\
\hline Hadika-i ......? & 300 \\
\hline Lügât-1 Fârîî & 255 \\
\hline Şerh-i Akâid & 20 \\
\hline
\end{tabular}




\begin{tabular}{|l|c|}
\hline Hayali Dav & 150 \\
\hline Sirac-1 Musalli & 20 \\
\hline Kuduri & 30 \\
\hline Ecrumiyye, Enmuzec & 60 \\
\hline Gülistân & 70 \\
\hline
\end{tabular}

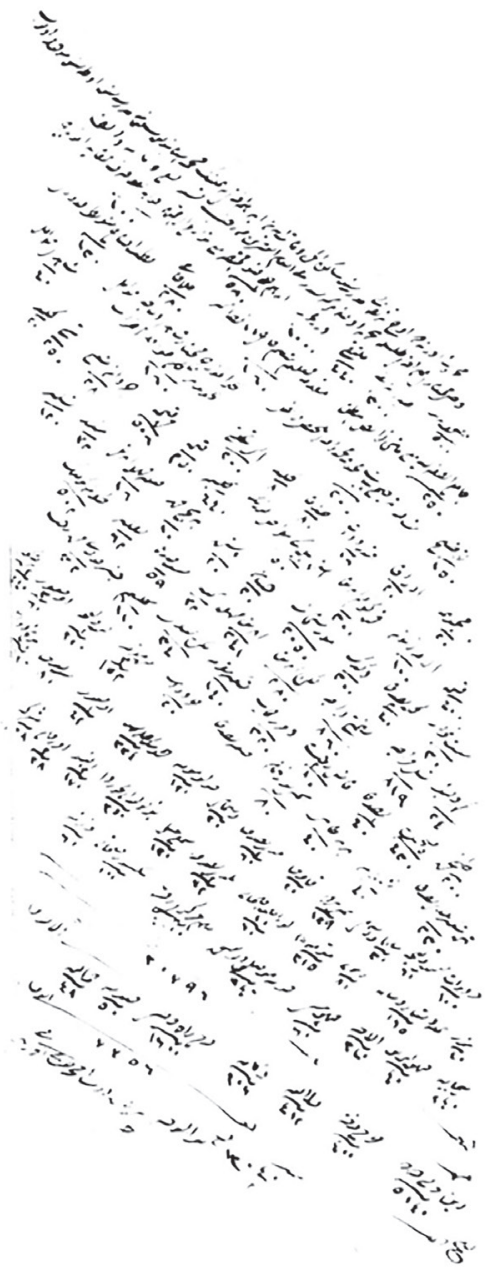




\section{3}

20 Receb 1109

(İstanbul ŞS, TSMA, 267, 179)

Mahruse-i Edirne'de Üçşerefeli Medresesi'nde sâkin iken vefât eden İbrahim Efendi b. Himmet'in mahmiye-i İstanbul'da Süleymaniye Medresesi'nde odası mevcud olup vasiyy-i muhtarı Ali Efendi talebiyle tahrir olunan terekesidir. Fi'l-yevmi'l-1şrin min Receb li-sene tisa ve mie ve elf.

\begin{tabular}{|l|c|}
\hline Kitap Adı & Fiyatı \\
\hline Mushâf-1 Şerîf & 500 \\
\hline Sadr-1 Şeri'a & 300 \\
\hline Mültekâ & 440 \\
\hline Dürer Gürer & 1000 \\
\hline İbrahim Halebî, Dav, Muhtasar ma'a ..., ..., ..., & 580 \\
\hline Sarf, Akayid, Enmuzec & 100 \\
\hline Câmi'u's-sağir Seyyid ma'a Metn-i Ferâiz Mantık & 250 \\
\hline Mukaddime-i Ta'lîm-i Müte'allim, Hacı Baba, Fikh-1 Ekber & 160 \\
\hline Molla Cami & 280 \\
\hline Kutb, İftitâh, Mutavassıt, Kuduri & 130 \\
\hline Tavzih & 150 \\
\hline Şafiye, Tercih-i Beyyinân, Mecmua-i Mahmud Efendi, Telhis, Ferâiz & 200 \\
\hline Nahiv, Enmuzec, Muhtar, Şâhidî, Dîbâce , Avamil, Tecvid-i Birgili, Kavâ'id-i İ'râb & 160 \\
\hline Şâhidî Avamil & 40 \\
\hline Mecmu'a & 20 \\
\hline Evrak & 20 \\
\hline Kubur devat & 16 \\
\hline
\end{tabular}




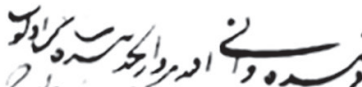

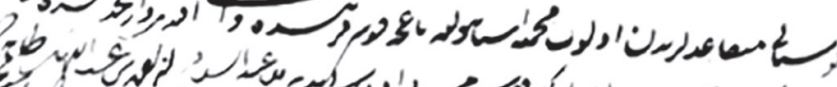

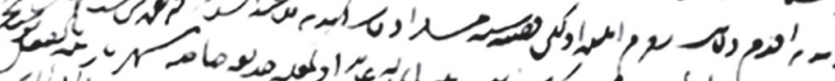

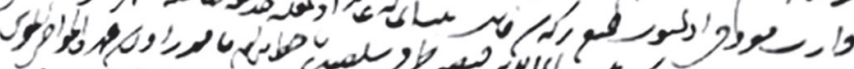

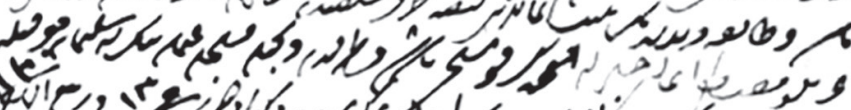
प 年 ه م

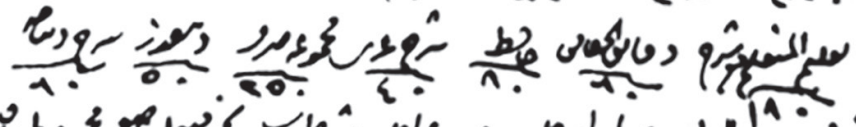
بَ:

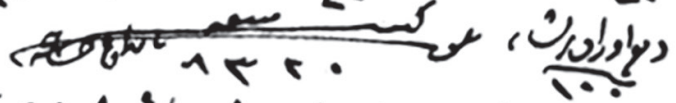

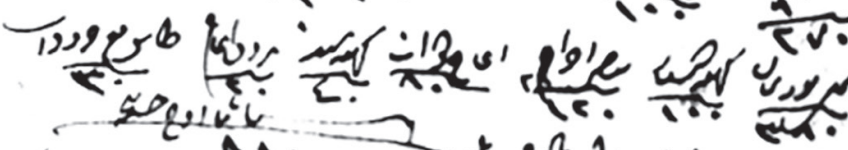

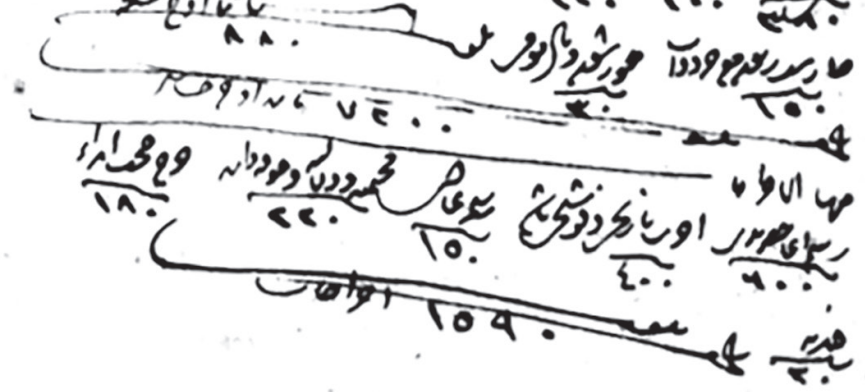


13 Rebiulahir 1110

(Kısmet-i Askeriye, 19, 94a)

Bostânî mütekâ‘idlerinden olup mahmiye-i İstanbul'da Bağçekapısı kurbunda Vânî Efendi Dârü'l-hadisînde sâkin olup bundan akdem vilâyet-i Rumelin'de Ölgün? Kasabasında misâfiren vefât iden Abdüsselâm bin Ahmed bin Abdullah'nn zahirde vâris-i ma'rûfu olmayup cemî‘ terekesi cânib-i beytü'l-mâle âid olmakla hadîka-i hâssa-i şehr-i yârîde bi'l-fi'l bostancıbaş1 vezâif-i mezbûresi beytü'l-mâllerini kabza taraf-1 şâhîden bâ-hatt-1 şerîf me'mûr olan umdetü'l-havass izzetlü Mustafa Ağa bin Abdullah bin Mehmed'in kuyumcubaşısı tarafindan vekîl-i müsecceli Osman Bey bin Süleyman ma'rifetiyle müteveffâ-i mezbûrun vech-i âtî üzere tahrîr olunan terekesidir ki zikr olunur. Fî 13 min Rebi‘u'l-âhir sene 1110.

\begin{tabular}{|c|c|c|}
\hline Kitap Adı & Adedi & Fiyatı \\
\hline Dürer Gürer & & 1200 \\
\hline Gülistân ma'a Bostan? & & 400 \\
\hline Lugât-i Türkî ma'a Arabî & 2 & 400 \\
\hline Lugât-i Ef'al? & & 100 \\
\hline Dav & 2 & 180 \\
\hline Mahmudiye & & 80 \\
\hline İftitâh & & 80 \\
\hline Menâsik & & 60 \\
\hline Bostan ma'a Şem‘î & & 600 \\
\hline Şerh-i Merah & & 50 \\
\hline Nahv-1 kâtibî? & & 50 \\
\hline Muhtasar & & 200 \\
\hline Telhis & & 120 \\
\hline Şerh-i Dibâce & & 60 \\
\hline Ta'birnâme ma'a Şem‘i & & 160 \\
\hline Muhyiddin & 1 & 8 \\
\hline Molla Câmi‘ & & 200 \\
\hline Çarperdi & & 200 \\
\hline Risâle-i Birgili & & 60 \\
\hline Kudbüddin ma'a şerh & & 120 \\
\hline Şâfiye & & 120 \\
\hline Kâfiye mecmu'as1 & & 80 \\
\hline
\end{tabular}




\begin{tabular}{|l|c|c|}
\hline Siyer-i Ebu'l-feth & 60 \\
\hline $\begin{array}{l}\text { Ta'limû'l-Müte'allim ma'a } \\
\text { şerh }\end{array}$ & & 180 \\
\hline Dakâyiku'l-hâkâyık & & 60 \\
\hline Hâfız & & 80 \\
\hline Şerh-i İzzî & & 40 \\
\hline Mecmua-i sarf & & 250 \\
\hline Dinkoz & & 50 \\
\hline Şerh-i Dibâce & & 60 \\
\hline Fenarî & & 920 \\
\hline Ferâiz & & 40 \\
\hline Mutavassit & & 60 \\
\hline Ahmed Çelebi & & 80 \\
\hline Muğrib Avâmil & & 40 \\
\hline Şerh-i ebyât & & 60 \\
\hline Nahve müte'allik Dav & & 60 \\
\hline Mecmu'a ve evrak & & 130 \\
\hline Kütüb & & 270 \\
\hline Def'a Evrâk-1 perişân & & 100 \\
\hline Yekûn-1 kütüb-i mebî‘a & & 6320 \\
\hline
\end{tabular}

